\title{
Does the Amniotic Fluid of Mice Contain a Viable Microbiota?
}

\section{OPEN ACCESS}

Edited by:

Damián Muzzio,

University of Greifswald, Germany

Reviewed by:

Eva Sverremark-Ekström,

Stockholm University, Sweden

Michelle Coleman,

Seattle Children's Research Institute,

United States

${ }^{*}$ Correspondence: Kevin R. Theis

ktheis@med.wayne.edu

Nardhy Gomez-Lopez

ngomezlo@med.wayne.edu

${ }^{+}$These authors have contributed equally to this work and share senior authorship

Specialty section:

This article was submitted to Microbial Immunology, a section of the journal

Frontiers in Immunology

Received: 22 November 2021 Accepted: 03 February 2022 Published: 28 February 2022

Citation:

Winters $A D$, Romero $R$,

Greenberg JM, Galaz J, Shaffer ZD, Garcia-Flores V, Kracht DJ, Gomez-Lopez N and Theis KR (2022) Does the Amniotic Fluid of Mice Contain a Viable Microbiota?

Front. Immunol. 13:820366. doi: 10.3389/fimmu.2022.820366

\begin{abstract}
Andrew D. Winters ${ }^{1,2,3}$, Roberto Romero ${ }^{1,4,5,6,7}$, Jonathan M. Greenberg ${ }^{1,8}$, Jose Galaz ${ }^{1,8}$, Zachary D. Shaffer ${ }^{1,9,10}$, Valeria Garcia-Flores ${ }^{1,8}$, David J. Kracht ${ }^{1,8}$, Nardhy Gomez-Lopez ${ }^{1,2,3,8^{*} t}$ and Kevin R. Theis ${ }^{1,2,3,8^{* T}}$
\end{abstract}

\begin{abstract}
1 Perinatology Research Branch, Division of Obstetrics and Maternal-Fetal Medicine, Division of Intramural Research, Eunice Kennedy Shriver National Institute of Child Health and Human Development, National Institutes of Health, U.S. Department of Health and Human Services, Detroit, MI, United States, 2 Perinatal Research Initiative in Maternal, Perinatal and Child Health, Wayne State University School of Medicine, Detroit, MI, United States, ${ }^{3}$ Department of Biochemistry, Microbiology, and Immunology, Wayne State University School of Medicine, Detroit, MI, United States, ${ }^{4}$ Department of Obstetrics and Gynecology, University of Michigan, Ann Arbor, MI, United States, ${ }^{5}$ Department of Epidemiology and Biostatistics, Michigan State University, East Lansing, MI, United States, ${ }^{6}$ Center for Molecular Medicine and Genetics, Wayne State University, Detroit, MI, United States, 7 Detroit Medical Center, Detroit, MI, United States, ${ }^{8}$ Department of Obstetrics and Gynecology, Wayne State University School of Medicine, Detroit, MI, United States, ${ }^{9}$ Department of Physiology, Wayne State University School of Medicine, Detroit, MI, United States, ${ }^{10}$ MD/PhD Combined Degree Program, Wayne State University School of Medicine, Detroit, MI, United States
\end{abstract}

The existence of an amniotic fluid microbiota (i.e., a viable microbial community) in mammals is controversial. Its existence would require a fundamental reconsideration of fetal in utero exposure to and colonization by microorganisms and the role of intra-amniotic microorganisms in fetal immune development as well as in pregnancy outcomes. In this study, we determined whether the amniotic fluid of mice harbors a microbiota in late gestation. The profiles of the amniotic fluids of pups located proximally or distally to the cervix were characterized through quantitative real-time PCR, 16S rRNA gene sequencing, and culture ( $N=21$ dams). These profiles were compared to those of technical controls for bacterial and DNA contamination. The load of 165 rRNA genes in the amniotic fluid exceeded that in controls. Additionally, the $16 \mathrm{~S}$ rRNA gene profiles of the amniotic fluid differed from those of controls, with Corynebacterium tuberculostearicum being differentially more abundant in amniotic fluid profiles; however, this bacterium was not cultured from amniotic fluid. Of the 42 attempted bacterial cultures of amniotic fluids, only one yielded bacterial growth Lactobacillus murinus. The $16 \mathrm{~S}$ rRNA gene of this common murine-associated bacterium was not detected in any amniotic fluid sample, suggesting it did not originate from the amniotic fluid. No differences in the 16S rRNA gene load, 16S rRNA gene profile, or bacterial culture were observed between the amniotic fluids located Proximally and distally to the cervix. Collectively, these data indicate that, although there is a modest DNA signal of bacteria in murine amniotic fluid, there is no evidence that this signal represents a viable microbiota. While this means that amniotic fluid is not a source of microorganisms for in utero colonization in mice, it may nevertheless contribute to fetal exposure to microbial components. The developmental consequences of this observation warrant further investigation.

Keywords: amniotic fluid, microbiome, microbiota, in utero colonization, sterile womb hypothesis, mouse model, low microbial biomass study 


\section{INTRODUCTION}

The mammalian amniotic cavity is filled with a protective liquid (i.e., amniotic fluid) that surrounds the fetus throughout gestation. Indeed, the amniotic fluid is essential for fetal development and maturation $(1,2)$. As such, the amniotic fluid is enriched with nutrients and growth factors $(1,3-5)$ and contains soluble [e.g. cytokines (6-27), anti-microbial molecules, etc. (28-33)] and cellular [e.g. innate and adaptive immune cells (34-40)] components that serve as an immunological barrier against invading pathogens. In clinical medicine, amniotic fluid is utilized as a diagnostic tool for assessing intra-amniotic inflammation and/or infection (4159), a condition that is strongly associated with obstetrical disease, the most detrimental of which is preterm birth (60). Therefore, the presence of microorganisms in the amniotic fluid is associated with adverse maternal and neonatal outcomes (6168 ), and the traditional view in obstetrics has been the "sterile womb hypothesis", which posits that the fetal environment is sterile and that the neonate first acquires a microbiota during the birthing process (69). However, recent investigations have posited that the placenta (70-82), the amniotic fluid (75, 8385), and the developing fetus (86-88) harbor resident microbiotas, and that the amniotic fluid microbiota functions as a primary source of microorganisms for initial colonization of the offspring in utero $(75,83,85,89,90)$. These juxtaposed views have sparked much debate $(69,84,91-95)$.

Investigations of human amniotic fluid in normal pregnancy have yielded contradictory results. Multiple studies using DNA sequencing techniques $(75,84,85,96-98)$ and/or quantitative real-time PCR $(83,97)$ have identified a molecular signal indicating the presence of an amniotic fluid microbiota; however, only one of these studies has demonstrated viable microorganisms from amniotic fluid through culture (75) (Supplementary Table 1). To date, no study has used cultivation, qPCR, and DNA sequencing concurrently to confirm the existence of a microbiota in human amniotic fluid during normal pregnancy. The concurrent use of multiple microbiological techniques in such investigations is important because a molecular signal of microorganisms is not necessarily equivalent to a true and viable microbiota $(69,83,99-101)$. For instance, the molecular signal may simply reflect circulating microbial DNA fragments (102). Furthermore, if there is an amniotic fluid microbiota, it has a very low microbial biomass and, therefore, reliance on molecular techniques such as DNA sequencing to characterize the presumed microbiota is susceptible to influences of background DNA contamination from laboratory environments, DNA extraction kits, PCR reagents, etc. (103). Yet, very few of the prior investigations that used DNA sequencing techniques to conclude the existence of a human amniotic fluid microbiota incorporated technical controls for background DNA contamination into their analyses $(84,97,98,104,105)$ (Supplementary Table 1). Hence, there remains uncertainty as to whether the human amniotic fluid and the intra-uterine environment, in general, harbor a microbiota.

The existence of an amniotic fluid microbiota would require a fundamental reconsideration of the role of intra-amniotic microorganisms in fetal development and pregnancy outcomes. Such reconsideration would require the implementation of animal models to perform mechanistic experimentation of host immune-microbe interactions. Yet, there have been only a limited number of studies investigating the presence of an amniotic fluid microbiota in animal models, specifically cattle, horses, sheep, goats, and rats (Supplementary Table 2). Although each of these studies used DNA sequencing techniques, very few included $\mathrm{qPCR}$, technical controls for background DNA contamination, or culture. Therefore, the objective of the current study was to determine whether the amniotic fluid of mice, the most widely utilized system for studying host immune-microbe interactions (106), harbors a viable microbiota by using technical controls, qPCR, 16S rRNA gene sequencing, and bacterial culture.

\section{MATERIALS AND METHODS}

\section{Study Subjects}

C57BL/6 mice were obtained from The Jackson Laboratory (Bar Harbor, ME, USA) and bred at the C.S. Mott Center for Human Growth and Development at Wayne State University, Detroit, MI, USA in the specific-pathogen-free (SPF) animal care facility. Mice were housed under a $12 \mathrm{~h}: 12 \mathrm{~h}$ light/dark cycle and had access to food (PicoLab laboratory rodent diet 5L0D; LabDiet, St. Louis, MO, USA), and water ad libitum. Females (8-12 weeks old) were mated with males of demonstrated fertility. Daily examination was performed to assess the appearance of a vaginal plug, which indicated 0.5 days post coitum (dpc). Dams were then housed separately from the males and their weights were checked daily. An increase in weight of $\geq 2 \mathrm{~g}$ by $12.5 \mathrm{dpc}$ confirmed pregnancy. All procedures were approved by the Institutional Animal Care and Use Committee (IACUC) (Protocol No. 18-03-0584) of Wayne State University.

\section{Sample Collection and Storage}

Twenty-one pregnant mice were included in this study (Figure 1). Pregnant mice were euthanized during the second half of pregnancy (13.5-18.5 dpc). The abdomen was shaved, and $70 \%$ ethanol was applied. Dams were placed on a sterile surgical platform within a biological safety cabinet. Study personnel wore sterile sleeves, masks, and powder-free sterile gloves during sample collection, and sterile disposable scissors and forceps were utilized. Iodine was applied to the abdomen with a sterile cotton swab, and after the iodine dried, a midline skin incision was performed along the full length of the abdomen. The peritoneum was longitudinally opened, using a new set of scissors and forceps, and the uterine horns were separated from the cervix and placed within a sterile petri dish. A sterile syringe with a $26 \mathrm{G}$ needle was utilized to obtain amniotic fluid from amniotic sacs proximal to the cervix and from amniotic sacs distal from the cervix. Due to the small volume of amniotic fluid often obtained from each amniotic sac $(<40 \mu \mathrm{l})$, amniotic fluid was obtained from two adjoining amniotic sacs and pooled. The amniotic fluid was aliquoted into two sterile tubes and transported immediately to the microbiology lab for bacterial 


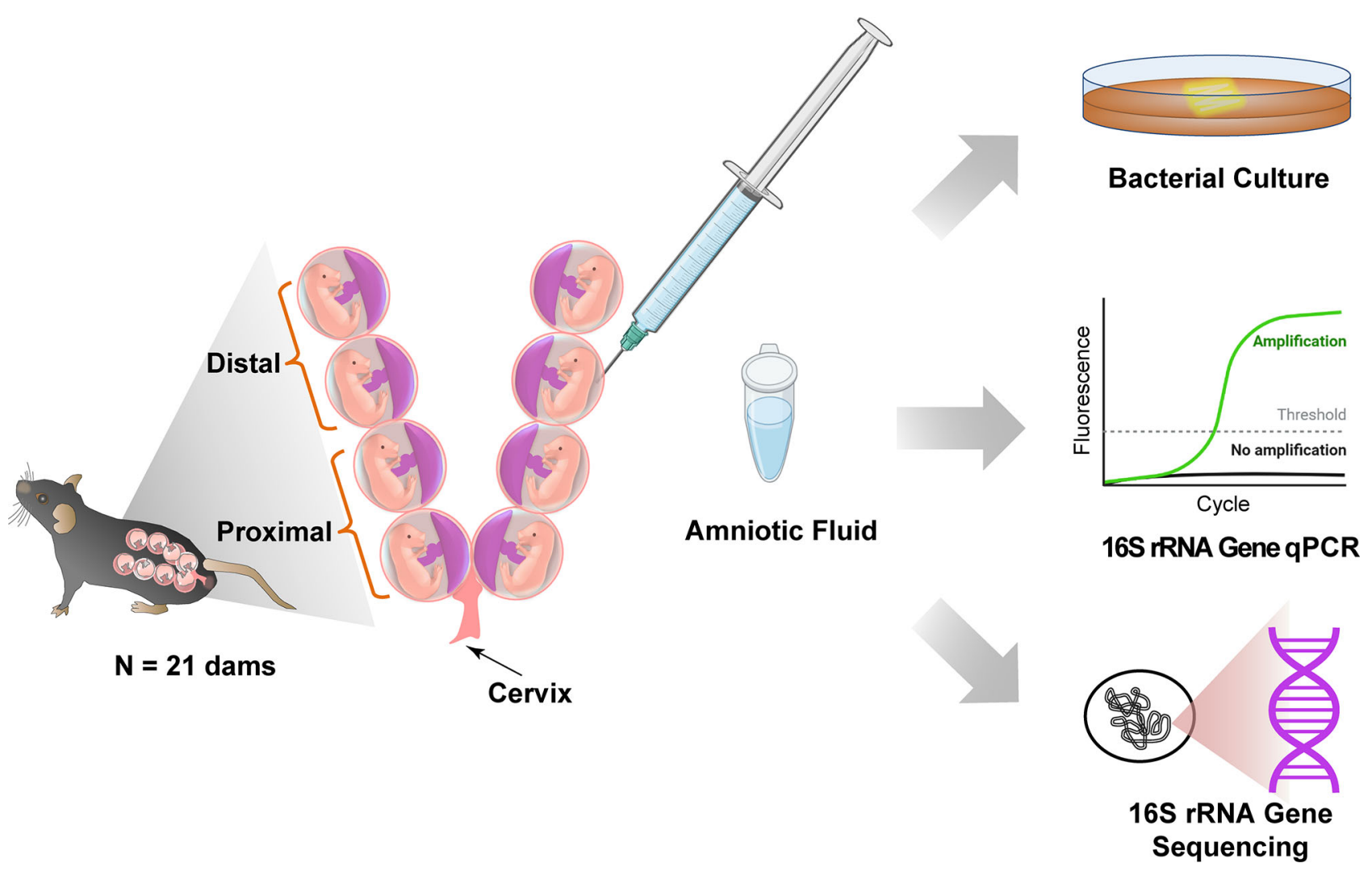

FIGURE 1 | Study design to test for the presence of bacteria in murine amniotic fluid. Created with BioRender.com.

culture and molecular analyses, respectively. The tube with the amniotic fluid for molecular analyses was stored at $-80^{\circ} \mathrm{C}$.

\section{Culture of Amniotic Fluid Samples}

For all mice, proximal and distal amniotic fluid samples $(\sim 40 \mu \mathrm{L}$ each) were cultured in $200 \mu \mathrm{L}$ of Brain-Heart-Infusion (BHI) broth supplemented with $5 \mathrm{mg} / \mathrm{L}$ of hemin and $2 \mu \mathrm{g} / \mathrm{L}$ of vitamin K1 under oxic and anoxic conditions for 48 hours. For the first eight mice in the study, $40 \mu \mathrm{L}$ of the $\mathrm{BHI}$ culture were then plated on supplemented BHI agar plates and cultured under the respective atmospheric condition for an additional 48 hours, and resultant bacterial isolates were taxonomically characterized. For the last 13 mice in the study, $40 \mu \mathrm{L}$ of the BHI culture were subsequently plated on supplemented BHI agar plates and cultured under the respective atmospheric condition if turbidity of the broth culture was observed after 48 hours of incubation. Any potential growth of bacteria in BHI broth cultures of proximal and distal amniotic fluid samples was then assessed through qPCR and 16S rRNA gene sequencing. As each amniotic fluid sample was cultured under oxic and anoxic conditions, $125 \mu \mathrm{L}$ each from the oxic and anoxic broth cultures were pooled and stored at $-80^{\circ} \mathrm{C}$. The $16 \mathrm{~S}$ rRNA gene loads and profiles of these amniotic fluid broth cultures were compared to those of six uninoculated BHI broth negative controls using qPCR and 16S rRNA gene sequencing.
Secondarily, after finding that DNA from the 16S rRNA gene of Corynebacterium tuberculostearicum, in particular, was more relatively abundant in proximal and distal amniotic fluid samples than in background technical controls (see Results section, Figure 3), we validated our culture protocol for the recovery and growth of C. tuberculostearicum. The C. tuberculostearicum type strain ATCC 35692 was ordered, and the freeze-dried pellet was recovered in approximately $5 \mathrm{~mL}$ of BHI broth. After 48 hours, growth from the primary inoculum was separated into $500 \mu \mathrm{l}$ aliquots with glycerol at a concentration of $17.5 \%$ and frozen at $-80^{\circ} \mathrm{C}$ for subsequent culture validation. Initially, $40 \mu \mathrm{l}$ of the frozen ATCC stock were inoculated into $400 \mu \mathrm{l}$ of BHI broth and then five 10-fold serial dilutions were performed. Tubes were incubated for 48 hours under aerobic conditions at $37^{\circ} \mathrm{C}$ and $40 \mu \mathrm{l}$ of the 48 -hour enrichment broth were plated onto $\mathrm{BHI}$ agar plates for an additional 48 hours of incubation. Colony counts were recorded and CFU (colony forming units) per $\mathrm{mL}$ and CFU limits of detection were calculated. All cultures were performed in duplicate and were CFU counts were averaged between the duplicate plates. Colony counts of the stock cultures indicated the original stock contained approximately 976,250 $\mathrm{CFU} / \mathrm{mL}$. Following 48 hours of broth enrichment, plated cultures were countable for the $10^{-3}$ (630 CFUs) and $10^{-4}$ dilutions (11 CFUs); no colonies were observed for the $10^{-5}$ dilution. After backcalculating the dilution and original 
inoculum volume, approximately four CFUs were inoculated into the $10^{-4}$ broth dilution tube, indicating that the limit of detection for C. tuberculostearicum was four CFUs.

\section{DNA Extraction}

Genomic DNA was extracted within a biological safety cabinet from amniotic fluid and BHI broth samples, as well as positive [i.e., human clean catch urine $(\mathrm{N}=3)$ ] and negative [i.e., blank DNA extraction kit $(\mathrm{N}=14)$, sterile BHI broth $(\mathrm{N}=6)$ ] controls using the DNeasy PowerLyzer Powersoil kit (Qiagen, Germantown, MD, USA), with minor modifications to the manufacturer's protocols as previously described (107, 108). Specifically, following UV treatment, $400 \mu \mathrm{L}$ of Powerbead solution, $200 \mu \mathrm{L}$ of phenol:chloroform:isoamyl alcohol ( $\mathrm{pH} 7-$ 8 ), and $60 \mu \mathrm{L}$ of preheated solution $\mathrm{C} 1$ were added to the provided bead tubes. Next, $250 \mu \mathrm{L}$ of an amniotic fluid or of a BHI sample were added to the tubes. When less than $250 \mu \mathrm{L}$ of amniotic fluid were available (9/41 samples, 21\%) a minimum of $100 \mu \mathrm{L}$ was added. Tubes were briefly vortexed, and cells were mechanically lysed in a bead beater for two rounds of $30 \mathrm{sec}$ each. Following 1 minute of centrifugation, supernatant was transferred to new tubes and $1 \mu \mathrm{L}$ of PureLink ${ }^{\mathrm{TM}}$ RNase A (20mg/mL, Invitrogen Carlsbad, CA, USA), $100 \mu \mathrm{L}$ of solution $\mathrm{C} 2$, and $100 \mu \mathrm{L}$ of solution $\mathrm{C} 3$ were added. Tubes were then incubated at $4^{\circ} \mathrm{C}$ for $5 \mathrm{~min}$. After a $1 \mathrm{~min}$ centrifugation, lysates were transferred to new tubes containing $650 \mu \mathrm{L}$ of $\mathrm{C} 4$ solution and $650 \mu \mathrm{L}$ of $100 \%$ ethanol. Lysates were then loaded onto filter columns $635 \mu \mathrm{L}$ at a time, centrifuged for $1 \mathrm{~min}$, and the flowthrough discarded. This wash process was repeated three times to ensure all lysate passed through the filter columns. Following the wash steps, $500 \mu \mathrm{L}$ of solution C5 was added to the filter columns and centrifuged for $1 \mathrm{~min}$. After discarding the flowthrough, the tubes were centrifuged for $2 \mathrm{~min}$ to dry the filter columns. The spin columns were transferred to clean $2.0 \mathrm{~mL}$ collection tubes and $60 \mu \mathrm{L}$ of pre-heated solution C6 were added directly to the center of the spin columns. Following a $5 \mathrm{~min}$ room temperature incubation, DNA was eluted by centrifuging for $1 \mathrm{~min}$. Purified DNA was then transferred to new $2.0 \mathrm{~mL}$ collection tubes and stored at $-20^{\circ} \mathrm{C}$.

\section{6s rRNA Gene Quantitative Real-Time PCR}

To measure total 16S rRNA gene abundance within samples, amplification of the V1-V2 region of the 16S rRNA gene was performed according to the protocol of Dickson et al. (109), with minor modifications as previously described (107, 108). The modifications consisted of using a degenerative forward primer (27f-CM: 5'-AGA GTT TGA TCM TGG CTC AG-3') and a degenerate probe with locked nucleic acids (+) (BSR65/17: [5'56FAM-TAA +YA+C ATG +CA+A GT+C GA-BHQ1-3']). Each $20 \mu \mathrm{L}$ reaction was performed with $0.6 \mu \mathrm{M}$ of $27 \mathrm{f}-\mathrm{CM}$ primer, $0.6 \mu \mathrm{M}$ of $357 \mathrm{R}$ primer (5'-CTG CTG CCT YCC GTA G3'), $0.25 \mu \mathrm{M}$ of BSR65/17 probe, $10.0 \mu \mathrm{L}$ of $2 \mathrm{X}$ TaqMan Environmental Master Mix 2.0 (Invitrogen), and $3.0 \mu \mathrm{L}$ of purified DNA or nuclease-free water. The following conditions were used to perform the total bacterial DNA qPCR: $95^{\circ} \mathrm{C}$ for 10 $\mathrm{min}$, and then $40 \mathrm{cycles}$ of $94^{\circ} \mathrm{C}$ for $30 \mathrm{sec}, 50^{\circ} \mathrm{C}$ for $30 \mathrm{sec}$, and $72^{\circ} \mathrm{C}$ for $30 \mathrm{sec}$. Each reaction was performed in triplicate using an ABI 7500 thermocycler (Applied Biosystems, Foster City, CA, USA). After normalization to the ROX passive reference dye, the 7500 Software version 2.3 (Applied Biosystems, Foster City, CA, USA) was used to analyze the raw amplification data with the default threshold and baseline settings. Calculation of the cycle of quantification $(\mathrm{Cq})$ values for the samples was based upon the mean number of cycles necessary for the exponential increase of normalized fluorescence.

\section{6s rRNA Gene Sequencing}

The V4 region of the $16 \mathrm{~S}$ rRNA gene was amplified and sequenced via the dual indexing strategy developed by Kozich et al. (110). The forward and reverse primers used were 515F: 5'-GTGCCAGCMGCCGCGGTAA-3' and 806R: 5'GGACTACHVGGGTWTCTAAT-3', respectively. Duplicate 20 $\mu \mathrm{L}$ PCR reactions were performed containing $0.75 \mu \mathrm{M}$ of each primer, 3.0 $\mu \mathrm{L}$ DNA template, $10.0 \mu \mathrm{L}$ of DreamTaq High Sensitivity Master Mix (Thermo Scientific, Waltham, MA, USA), and $5 \mu \mathrm{L}$ of DNase-free water. Reaction conditions were as follows: $95^{\circ}$ for $3 \mathrm{~min}$, followed by 38 cycles of $95^{\circ} \mathrm{C}$ for $45 \mathrm{sec}$, $50^{\circ} \mathrm{C}$ for $60 \mathrm{sec}$, and $72^{\circ} \mathrm{C}$ for $90 \mathrm{sec}$, followed by an additional elongation at $72^{\circ} \mathrm{C}$ for $10 \mathrm{~min}$. The duplicate PCR reactions were then pooled, and DNA was quantified with a Qubit 3.0 fluorometer and the Qubit dsDNA assay kit (Life Technologies, Carlsbad, CA, USA) following the manufacturer's protocol. Samples were pooled in equimolar concentrations and purified by using the Cytiva Sera-Mag Select DNA Size Selection and PCR Clean-Up Kit (Global Life Sciences, Little Chalfont, Buckinghamshire, UK), according to the manufacturer's instructions. Illumina MiSeq sequencing was performed at the Michigan State University Research Technology Support Facility Genomics Core. Specifically, sequencing was performed in a $2 \times 250 \mathrm{bp}$ paired end format using a 500 cycle v2 reagent cartridge.

Raw sequence reads were processed by using DADA2 (v 1.12) (111). An analysis of $16 \mathrm{~S}$ rRNA gene amplicon sequence variants (ASVs), defined by $100 \%$ sequence similarity, was performed using DADA2 in R (v 3.5.1) (https://www.R-project.org) and the online MiSeq protocol (https://benjjneb.github.io/dada2/tutorial. html) with minor modifications. These modifications included allowing truncation lengths of $250 \mathrm{bp}$ and $150 \mathrm{bp}$ and a maximum number of expected errors of $2 \mathrm{bp}$ and $7 \mathrm{bp}$ for forward and reverse reads, respectively. To allow for increased power to detect rare variants, sample inference allowed for the pooling of samples. Additionally, samples in the resulting sequence table were pooled prior to removal of chimeric sequences. Sequences were then classified by using the silva_nr_v132_train_set database with a minimum bootstrap value of $80 \%$, and sequences derived from Archaea, chloroplast, or Eukaryota were removed.

The $\mathrm{R}$ package decontam version 1.6 .0 (112) was used to identify ASVs that were likely potential background DNA contaminants based on their distribution among biological samples (amniotic fluid and BHI cultures) and negative controls (blank DNA extractions and stock BHI broth) using the "IsNotContaminant" method. Identification of contaminant 
ASVs was assessed for amniotic fluid and BHI cultures independently. An ASV was determined to be a contaminant, and was removed from the dataset, if it had a decontam $\mathrm{P}$ score $\geq$ 0.7 and was present in at least $20 \%$ of the negative controls with an overall average relative abundance of at least $1.0 \%$.

\section{Statistical Analysis}

Prior to statistical analyses, the bacterial profiles of proximal and distal amniotic fluid samples and blank DNA extraction controls were rarefied to 1,366 sequence reads (set.seed $=1$ ) using phyloseq (113). The bacterial profiles of proximal and distal BHI culture samples and stock BHI broth samples were rarefied to 21,227 sequence reads. Variation in the bacterial profiles was visualized through Principal Coordinates Analyses (PCoA) using the $\mathrm{R}$ package vegan version 2.5-6 (114). Alpha diversity values and 16S rRNA gene signal (qPCR Cq) values across sample groups were compared by using the "wilcox.test" function in $\mathrm{R}$ version 3.6.0. Beta diversity of amniotic fluid bacterial profiles was characterized using the Bray-Curtis dissimilarity index. Bacterial community structure of amniotic fluid and BHI culture samples was compared by using PERMANOVA (115) with the "adonis" function in the R package vegan version 2.5-6 (114). Assessment of differentially abundant taxa across sample groups was performed by using Linear Discriminant Analysis Effect Size, or LEfSe (116), with default parameters. Analysis of the phylogenetic relationships of selected ASVs and other bacteria was performed using the Neighbor-Joining method (117) in MEGA 6 software (118) with the Maximum Composite Likelihood method and bootstrapping of 1,000 replicates, allowing for transitions and transversions.

\section{RESULTS}

\section{Murine Amniotic Fluid Contains Bacterial 16s rRNA Gene Copies}

Amniotic fluid was collected from amniotic sacs located proximally and distally to the cervix under aseptic conditions from 13.5 - $18.5 \mathrm{dpc}$ (Figure 1). First, we evaluated the absolute abundance of bacterial 16S rRNA gene copies in amniotic fluid using qPCR. There was a significantly higher $16 \mathrm{~S}$ rRNA gene signal in proximal $(W=6, p=0.0003)$ and distal $(W=16, p=$ 0.004) amniotic fluid samples than in blank extraction controls. However, the $16 \mathrm{~S}$ rRNA gene signal did not differ between paired proximal and distal samples $(V=89, p=0.571)$ (Figure 2A). These results indicate that the murine amniotic fluid contains 16S rRNA gene copies, and that their concentrations do not depend on proximity to the cervix.

\section{6s rRNA Gene Profiles Differ Between Murine Amniotic Fluid and Controls}

Next, the 16S rRNA gene profiles of the amniotic fluid samples were characterized by using nucleotide sequencing and the generation of amplicon sequence variants (ASVs). Prior to removing potential background DNA contaminants, the $16 \mathrm{~S}$ rRNA gene profiles of both the proximal and distal amniotic fluid samples differed from that of negative controls (PERMANOVA $F=2.343, R^{2}=0.068, p=0.0001$ and $F=1.806$, $R^{2}=0.052, p=0.008$, respectively) (Figure 2B). The most prominent ASVs in the proximal and distal amniotic fluid samples and technical controls were Staphylococcus, Pseudomonas, and Enterobacteriaceae (Figure 2C). There were differentially abundant taxa between the amniotic fluid samples and negative controls (Figures 3A, B). Most notably, multiple ASVs classified as Corynebacterium were more abundant in proximal (ASV 10) and distal (ASVs 10, 31 and 572) amniotic fluid samples than in controls (Figures 3A, B). These corynebacteria were most closely related to C. tuberculostearicum, C. mucifaciens, C. ureicelerivorans, C. ihumii, and C. pilbarense (Figure 3C). Additional taxa that were differentially abundant in proximal amniotic fluid samples compared to controls were Streptococcus (ASV 13), Pseudomonas (ASV 24), and Sphingobium (ASV 33) (Figure 3A).

To address whether the $16 \mathrm{~S}$ rRNA gene signals in amniotic fluid may represent potential background DNA contamination, the $\mathrm{R}$ package decontam was used to identify and remove likely contaminants. After contaminants were removed from the dataset, the ASVs with the highest mean relative abundance in both proximal and distal amniotic fluid samples were Corynebacterium and Streptococcus (Figure 4A). This contrasts with the profile structure before contaminant removal (Supplemental Figure 1). The 16S rRNA gene profiles of paired proximal and distal amniotic fluid samples did not differ in richness (Chaol richness) $(V=58, p=0.083)$ or in evenness (Shannon-Wiener diversity) $(V=76, p=0.294)$. The structure of these profiles did not differ either by mouse dam ID (PERMANOVA $F=0.992, R^{2}=0.495, p=0.551$ ) or proximity to the cervix $\left(F=1.215, R^{2}=0.030, p=0.089\right)$ (Figure 4B). Collectively, these results indicate that, if there is a murine amniotic fluid microbiota, it is largely comprised of Corynebacterium and Streptococcus, both of which are readily grown on brain heart infusion medium $(119,120)$, which was the medium used for the culture component of this study (see Materials and Methods section Culture of Amniotic Fluid Samples).

\section{Murine Amniotic Fluid Does Not Contain a Viable Microbiota}

Forty-two amniotic fluid samples were cultured for bacteria, and only one amniotic fluid sample (Dam \#3 distal) yielded bacterial growth (Figure 5A). For this sample, multiple colonies of a single bacterial morphotype (Gram positive rod) were ultimately recovered under oxic and anoxic conditions. The partial $16 \mathrm{~S}$ rRNA genes (703 bp) of these isolates were at least $99.7 \%$ identical to Lactobacillus murinus NBRC 14221 (NR_112689). The distal amniotic fluid sample from Dam \#3 did not have 16S rRNA gene concentrations outside the range of other amniotic fluid samples in the study (Figure 2A), which would be expected if it was truly and uniquely populated with L. murinus.

Secondarily, for 13/21 dams (i.e., the last 13 dams sampled), we further characterized the $16 \mathrm{~S}$ rRNA gene concentration and profile of the amniotic fluid-inoculated BHI broths and 
A

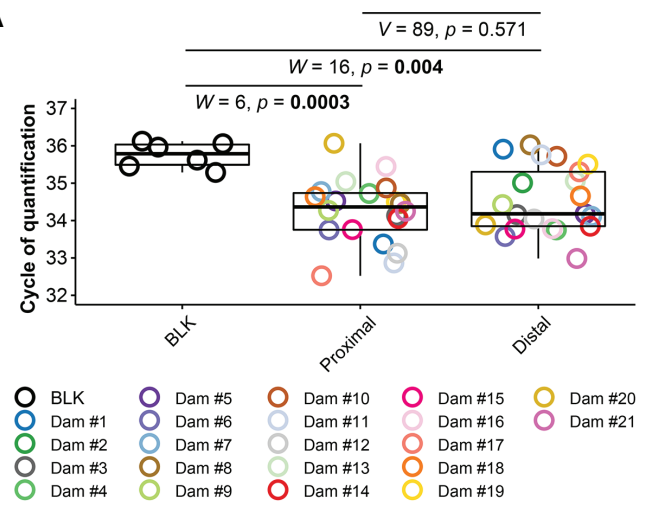

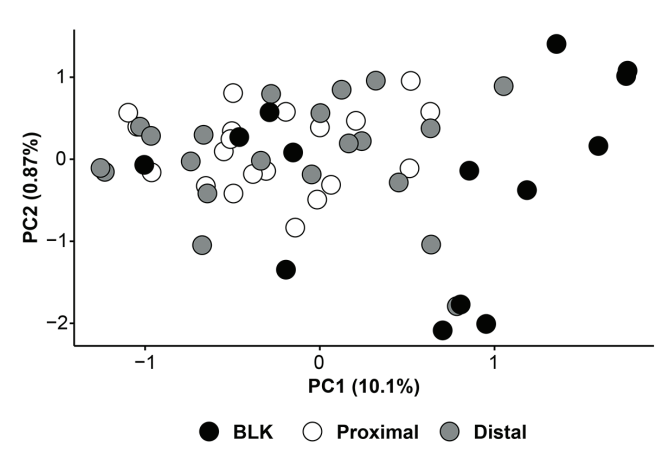

C

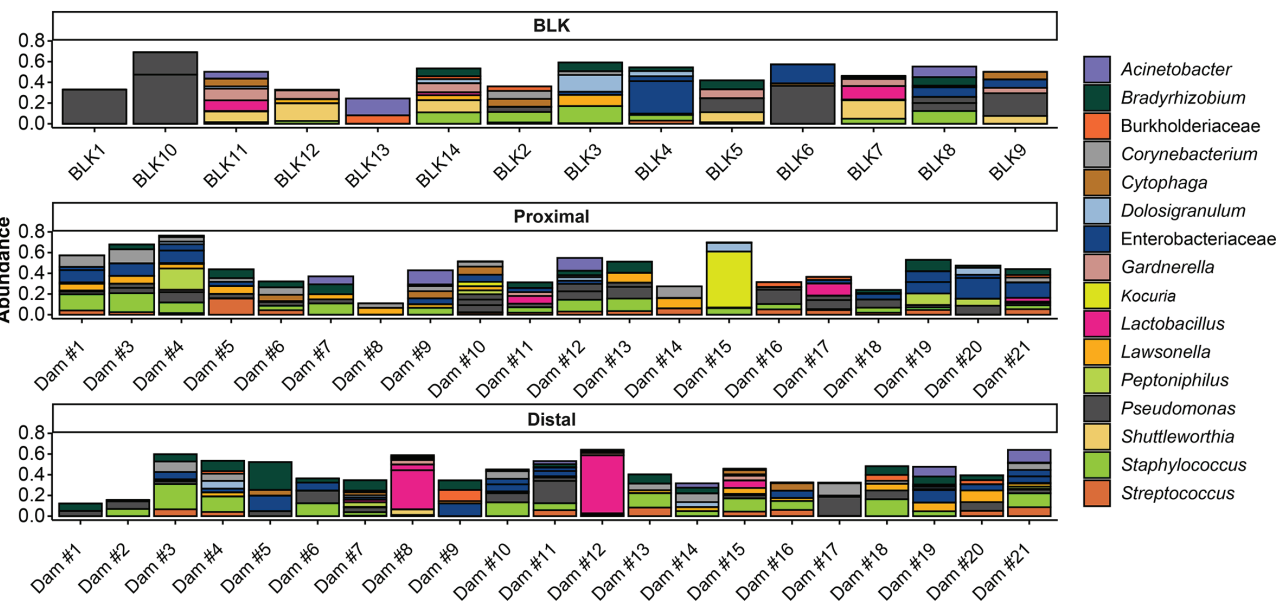

FIGURE 2 | 16S rRNA gene qPCR and sequencing results for amniotic fluid and blank control samples. (A) Cycle of Quantification (Cq) values from qPCR of proximal and distal amniotic fluid and blank control (BLK) samples. (B) Principal coordinate analysis (PCoA) illustrating variation in 16S rRNA gene profiles among proximal and distal amniotic fluid and blank control samples. Similarities in the 16S rRNA gene profiles were characterized using the Bray-Curtis similarity index. (C) Taxonomic classifications of the 20 amplicon sequence variants (ASVs) with highest relative abundance across all proximal and distal amniotic fluid and blank control samples. Bars of identical color within the same sample indicate multiple ASVs with the same bacterial taxonomic classification. The DNA extract of the proximal amniotic fluid sample from Dam \#2 did not yield a 16S rRNA gene sequence library.

compared these data to those of stock control broth. Overall, the 16S rRNA gene signal of inoculated broths did not exceed that of stock control broth (Figure 5B). Additionally, the 16S rRNA gene profile of both the proximal and distal amniotic fluid cultures did not differ from those of the stock BHI control broth (PERMANOVA $F=0.702, R^{2}=0.04, p=0.602$ and $F=$ $0.918, R^{2}=0.051, p=0.461$, respectively) (Figures 5C, D). Like the data for 16S rRNA gene concentration (Figure 5B), the $16 \mathrm{~S}$ rRNA gene profile did not differ between paired proximal and distal amniotic fluid inoculated broths (Figures 5C, D). After removal of contaminants from the dataset using decontam, only one-half of the paired amniotic fluid culture samples $(\mathrm{N}=7)$ had at least 500 sequence reads remaining (i.e., the majority of sequence data from amniotic fluid inoculated broths was identified as likely DNA contamination). The structures of the proximal and distal culture 16S rRNA gene profiles did not vary by mouse dam ID (PERMANOVA $F=0.815, R^{2}=0.409 p=$ $0.807)$ or differ based on proximity to the cervix $\left(F=1.057, R^{2}=\right.$ $0.089, p=0.317)$.
Taken together, using culture and molecular interrogations of culture broths, these data provide no evidence of bacterial growth in proximal or distal amniotic fluids.

\section{DISCUSSION}

In the current study, we utilized qPCR, 16S rRNA gene sequencing, and bacterial culture to investigate the presence and consistency of bacterial signals in murine amniotic fluids. Molecular techniques indicated the presence of a 16S rRNA gene signal in the amniotic fluids, yet this signal was not verified through culture as coming from a viable microbiota.

\section{Prior Reports of an Amniotic Fluid Microbiota in Normal Human Pregnancy}

Investigations that used qPCR, 16S rRNA gene sequencing, or cultivation to determine the presence of a human amniotic fluid microbiota in normal pregnancy have yielded inconsistent 
A

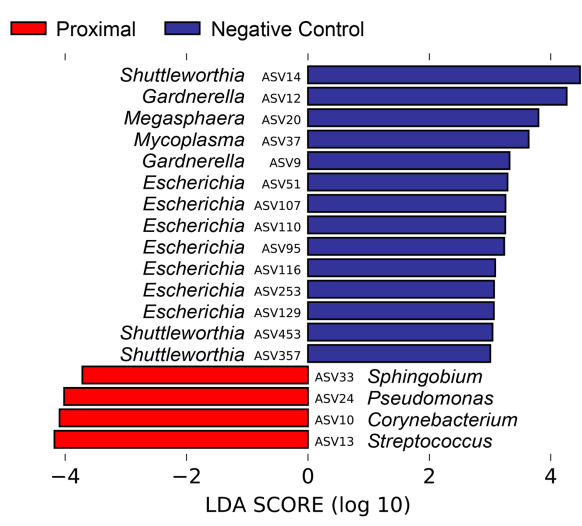

C

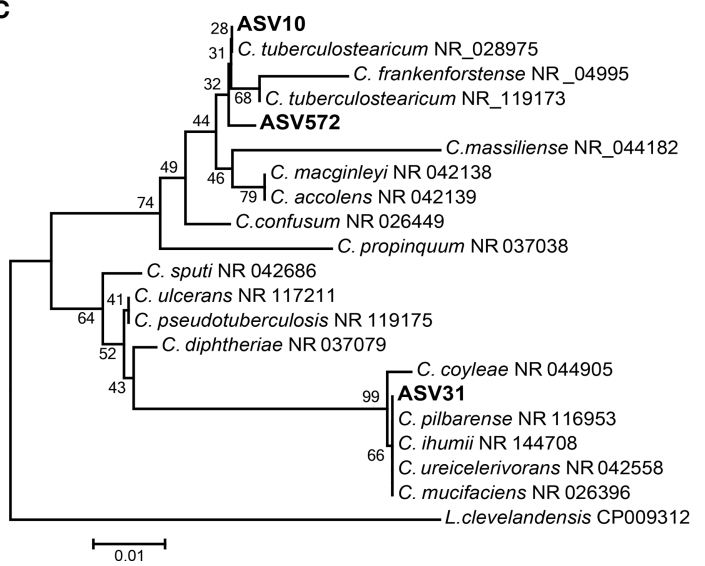

B

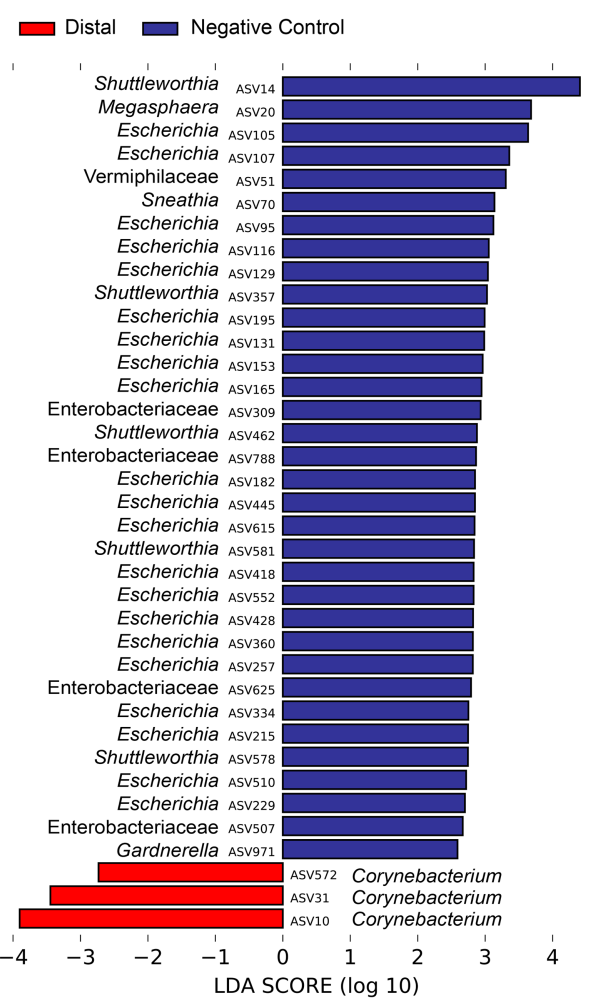

FIGURE 3 | Differentially abundant amplicon sequence variants (ASVs) in proximal and distal amniotic fluid and blank control samples. (A) proximal and (B) distal amniotic fluid samples compared to blank DNA extraction controls as determined by Linear discriminant analysis effect size analyses. (C) Dendrogram of the three differentially abundant Corynebacterium ASVs in amniotic fluid samples and partial 16S rRNA gene sequences of closely related bacterial type strains. Numbers at the nodes are maximum-likelihood bootstrap values. Scale bar indicates the number of nucleotide substitutions per site.

findings $(75,83-85,96-98,104,105,121)$. This is likely due in part to insufficient methods such as a lack of multiple complementary techniques for bacterial detection and characterization and/or a lack of appropriate technical controls. Notably, of these studies, only one reported the isolation of bacteria (Propionibacterium [Cutibacterium] and Staphylococcus) from human amniotic fluid of women who delivered a term neonate (75). These bacteria were also identified in the 16S rRNA gene profiles of amniotic fluid; however, they are typical inhabitants of the human skin and may therefore represent skin contaminants introduced during cesarean delivery (122).

Overall, of the studies which performed 16S rRNA gene sequencing to investigate the existence of a human amniotic fluid microbiota in normal pregnancies $(75,84,85,96-98,104$, $105,121)$, only five included technical controls for background DNA contamination $(84,97,98,104,105)$. Three concluded the existence of an amniotic fluid microbiota, although these studies did not include a culture component $(84,97,98)$. The first study (84) reported that $83.7 \%(36 / 43)$ of amniotic fluid samples had a 16S rRNA gene signal, with varying degrees of Propionibacterium
(Cutibacterium) acnes, Staphylococcus epidermidis, Ralstonia, Streptococcus anginosus, and Peptoniphilus dominance. The second study (97) reported that $19.9 \%(238 / 1,198)$ of amniotic fluid samples yielded a $16 \mathrm{~S}$ rRNA gene signal; they were dominated by Saccharibacteria, Acidovorax, Tepidimonas, Pelomonas, and Streptococcus oligofermentans. In the third study (98), only $13.8 \%(4 / 29)$ of amniotic fluid samples had a detectable 16S rRNA gene signal, with Actinomyces, Cutibacterium, Staphylococcus, and Streptococcus being most relatively abundant. Thus, the most reported bacterial taxa detected in human amniotic fluid investigations were Staphylococcus and Cutibacterium, two typical skin bacteria (122). These results illustrate the need for more comprehensive investigations that implement multiple complementary modes of microbiologic inquiry as well as the need for robust technical controls.

\section{Existence of an Amniotic Fluid Microbiota in Animal Models}

In cattle, three investigations utilized $16 \mathrm{~S}$ rRNA gene sequencing to explore the presence of an amniotic fluid microbiota (123- 

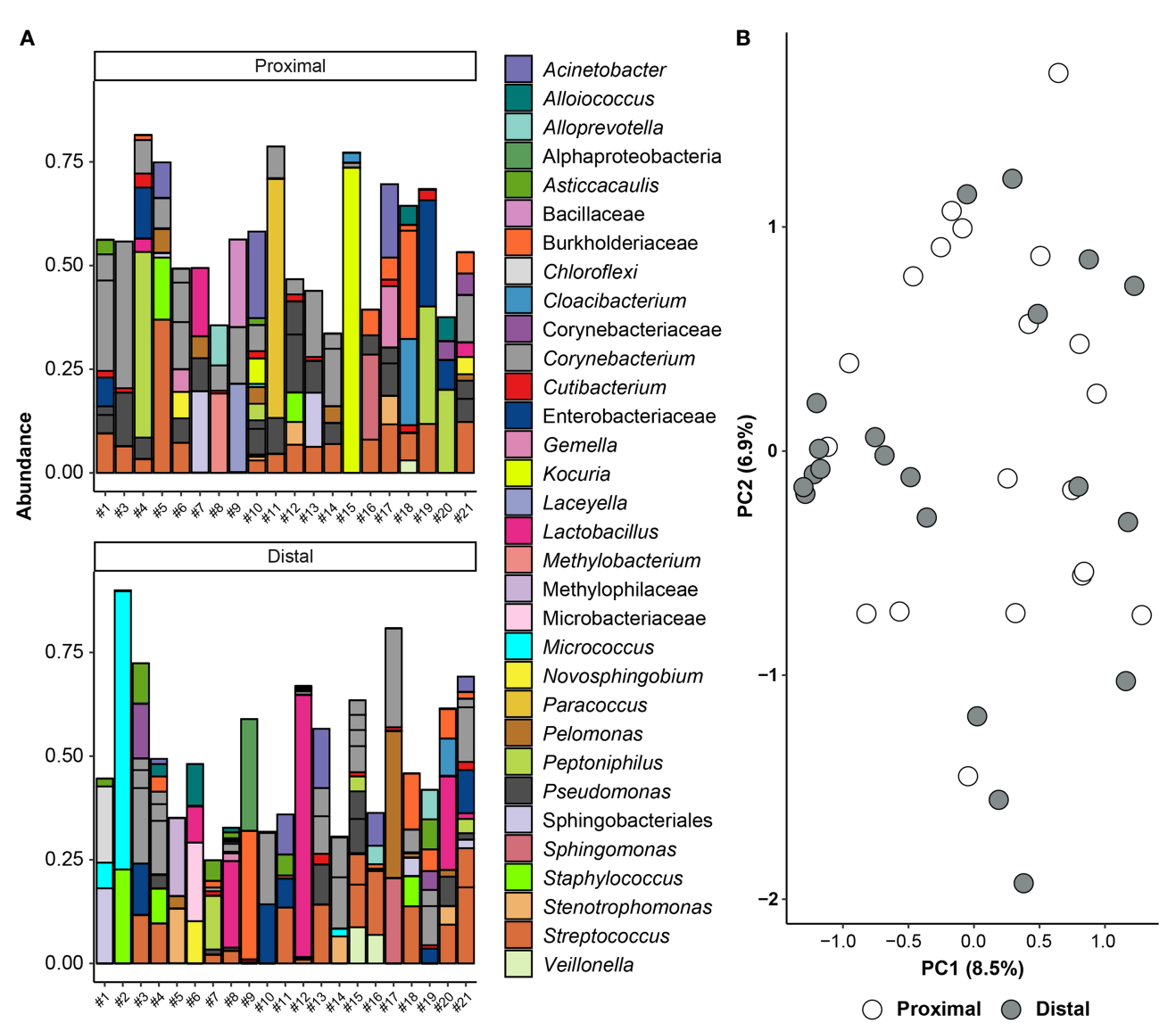

FIGURE 4 | Amniotic fluid sequencing results after the removal of likely contaminating sequences. (A) Bar graph showing the taxonomy of the 45 amplicon sequence variants (ASVs) with highest relative abundance across all proximal and distal amniotic samples. Bars of identical color within the same sample indicate multiple ASVs with the same bacterial taxonomic classification. The DNA extract of the proximal amniotic fluid sample from Dam \#2 did not yield a 16S rRNA gene sequence library. (B) Principal coordinate analysis (PCOA) illustrating variation in 16S rRNA gene profiles among proximal and distal amniotic fluid samples. The 16S rRNA gene profiles were characterized using the Bray-Curtis similarity index.

125) (Supplementary Table 2). Two concluded the existence of an amniotic fluid microbiota, using this approach (123, 124); however, one study, which also included GPCR, and culture, concluded that the bacterial signals in the amniotic fluid did not exceed those in controls (125). In two investigations of horses and goats, a microbiota was identified in the amniotic fluid using $16 S$ rRNA gene sequencing $(126,127)$. However, in a study of sheep, the amniotic fluid was determined to be sterile using qPCR, and 16S rRNA gene sequencing (128). Clearly, in bovids and equids, the existence of an amniotic fluid microbiota remains uncertain.

In the only study to date of rodents (89), 16S rRNA gene sequencing was used to demonstrate that amniotic fluid microbiota profiles were pup- and dam-specific in a rat model, yet they were not different from those of the placenta or fetal intestine. The primary bacteria detected were identified as Lachnospiraceae, Ruminococcaceae, Bacteroidaceae, Veillonellaceae, Rikenellaceae, and Propionibacteriaceae (89). However, this study did not include qPCR, or culture components, so it is not clear whether these $16 \mathrm{~S}$ rRNA gene signals represent a viable amniotic fluid microbiota.

\section{Our Findings in the Context of Prior Studies}

The in utero colonization hypothesis posits that developing fetuses are colonized by microorganisms prior to labor and delivery. Two recent studies provided evidence for in utero colonization in humans $(87,88)$. In the first study (87), fluorescence in situ hybridization and scanning electron microscopy revealed sparse patches of bacteria-like structures in the intestinal meconium of second trimester fetuses from terminated pregnancies. 16S rRNA gene sequencing identified Micrococcaceae and Lactobacillus as being enriched in the meconium, and Micrococcus was ultimately cultured from it. In the second study (88), bacteria-like structures were again visualized in intestinal samples from second trimester fetuses from terminated pregnancies, this time using RNA-in situ hybridization and scanning electron microscopy. A low but consistent 16S rRNA gene signal was detected through qPCR, and DNA sequencing, and Staphylococcus, Lactobacillus, and Gardnerella, among other bacteria, were cultured from fetal intestinal tissues. However, some of the results of these studies 


\section{A}

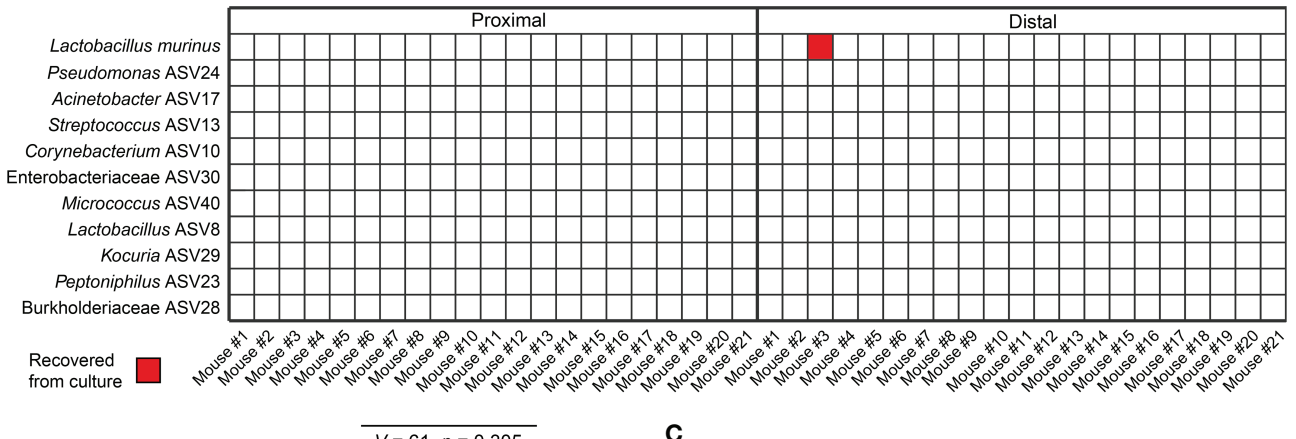

B
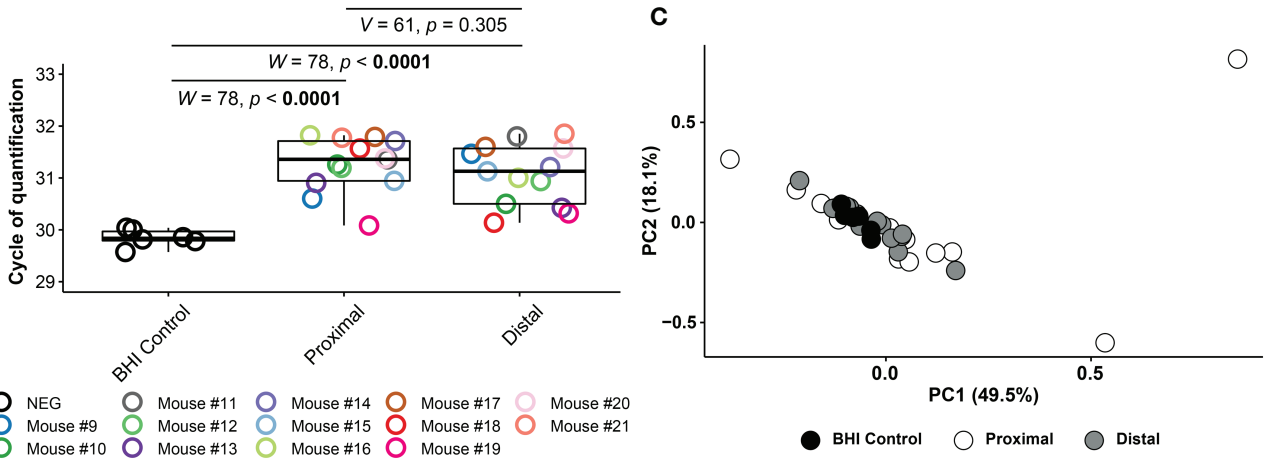

D

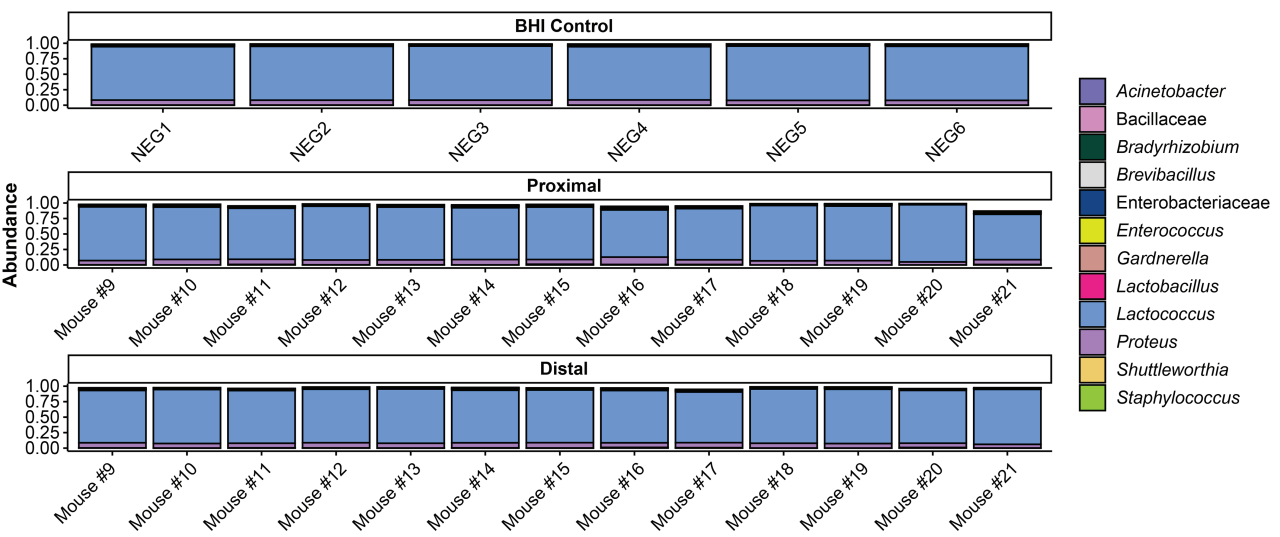

FIGURE 5 | Amniotic fluid culture and blank control 16S rRNA gene qPCR and sequencing results. (A) Bacterial cultivation results for proximal and distal amniotic fluid samples. (B) Cycle of quantification values from qPCR on amniotic fluid culture samples and BHI culture medium controls. (C) Principal coordinate analysis (PCOA) of bacterial relative abundance data from amniotic fluid samples and BHI culture medium controls. (D) Relative abundance of bacteria in the 16S rRNA gene profiles of amniotic fluid samples and BHI culture medium controls. Bars of identical color within the same sample indicate multiple amplicon sequence variants with the same bacterial taxonomic classification.

have been challenged. For example, there are concerns that the $16 \mathrm{~S}$ rRNA gene sequence data reported in the first study (87) were influenced by batch effects, and that the micrographs of bacteria-like structures did not actually reveal bacterial cells (93) [but see reply by (129)]. A more general concern with both studies is that microorganisms may have been introduced to the sampled fetuses during the delivery process. This is why the in utero colonization hypothesis can only be evaluated using samples obtained from cesarean deliveries without labor (69, $86,130)$. For example, in a recent study of human fetal meconium obtained from rectal swabs during non-labored elective cesarean deliveries (130), the 16S rRNA gene profiles of meconium samples and technical controls were indistinguishable. Cultures of fetal meconium yielded isolates of only Staphylococcus and Propionibacterium (Cutibacterium), typical commensal skin bacteria (122), and there was generally no matching $16 \mathrm{~S}$ rRNA gene signal for these bacteria in the meconium samples, suggesting they were contaminants. Therefore, the in utero colonization hypothesis remains in question.

Nevertheless, if there is in utero colonization and a viable fetal microbiota, there are two potential sources: hematogenous transfer through the placenta and ingestion of colonized amniotic fluid $(75,86,131)$. Recent studies reported that both 
the human placenta $(70-78,80-82)$ and amniotic fluid $(75,83-$ 85) consistently harbor resident bacterial communities. However, the vast majority of these studies have relied principally on data obtained from DNA sequencing technologies, and when samples possess either low or no microbial biomass, they are susceptible to the influence of background DNA contamination (103, 132-134). Indeed, other recent studies that have emphasized the identification of likely DNA contamination have concluded that there is not consistent evidence of resident bacterial communities in the human placenta $(133,135-141)$ or amniotic fluid $(104,105)$.

While the in utero colonization hypothesis and the existence of a placental and/or amniotic fluid microbiota have been frequently investigated in humans, they have been only rarely investigated in mice $(86,101,107,142)$. An initial study revealed bacterial signals in the placenta and fetal intestine of mice through 16S rRNA gene qPCR, and sequencing, and suggested the placenta as the likely origin of fetal bacterial DNA (101). In a second study (86), bacteria were visualized in the fetal intestine of mice through fluorescence in situ hybridization. Bacteria were also detected in fetal tissues through 16S rRNA gene sequencing, and potential sources of these signals were suggested to be the placenta and amniotic membranes. Furthermore, culture of fetal tissues yielded bacterial isolates, primarily Lactobacillus (86). However, subsequent studies have yielded no consistent evidence of a placental or a fetal microbiota in mice $(107,142)$. For instance, we attempted to characterize the placental and fetal (brain, lung, liver, intestine) microbiotas of mice using 16S rRNA gene qPCR, sequencing, and culture (107). Bacterial loads of placental and fetal tissues did not exceed those of technical controls, nor did they yield substantive 16S rRNA gene sequence libraries. Recovery of bacteria from placental and fetal tissues through culture was rare. For example, culture of the fetal intestine yielded only a single isolate of Staphylococcus hominis, a common human commensal skin bacterium (122) thus, a likely contaminant. Therefore, as is the case with human investigations, investigations of the in utero colonization hypothesis and of placental and fetal microbiotas in mice have yielded disparate results.

In the current study, we focused specifically on whether there is a viable microbiota in murine amniotic fluid, which has not been previously evaluated. Quantitative PCR showed a significantly greater $16 \mathrm{~S}$ rRNA gene signal in both proximal and distal amniotic fluid samples than in the negative controls, indicating the presence of $16 \mathrm{~S}$ rRNA gene copies in amniotic fluid samples regardless of proximity to the cervix. These findings are consistent with the $\mathrm{qPCR}$ results of a prior study of cattle amniotic fluid (124).

Our investigation using $16 \mathrm{~S}$ rRNA gene sequencing detected higher relative abundances of DNA from Corynebacterium spp., Pseudomonas, Sphingobium, and Streptococcus in the amniotic fluid of mice than in technical controls (Figure 3 ). Corynebacterium spp. and Streptococcus spp. are resident microbiota of mammals, including humans and mice (122, 143-145). However, these microorganisms have also been identified as common bacterial DNA contaminants in studies with low microbial biomass $(98,103,132)$. Corynebacterium spp. are aerobic, non-spore-forming, Gram-positive bacteria (119) that have been identified as members of the mouse skin (143) and respiratory (144) microbiotas. Specifically, Corynebacterium tuberculostearicum (ASV 10) has been previously detected in human amniotic fluid using molecular techniques; however, this bacterium was not recovered using conventional culture methods $(84,146)$. The Streptococcus ASV detected in the current study (ASV 13) had an identical sequence match with multiple members of the Mitis group of the genus Streptococcus, which are common inhabitants of the oral cavity and upper respiratory tract in humans (147) and have been detected in the lungs of mice (107). Pseudomonas is widely distributed amongst mammals and the broader environment (148). In our study, BLAST analysis was performed on ASV 24 (Pseudomonas), but a species-level taxonomy could not be assigned, indicating that the V4 region of the $16 \mathrm{~S}$ rRNA gene is not adequate for differentiation of the Pseudomonas species, at least those detected herein. Sphingobium is typically an environmental microorganism (149). In the current study, BLAST analysis for ASV 33 showed that it was identical to the typical soil bacteria $S$. naphthae, S. olei, and S. soli (150-152). A single case was reported of $S$. olei causing peritonitis via infection of an indwelling peritoneal catheter in a patient with end stage renal disease (153). In summary, although some of these microorganisms have been found in biologically relevant sites, the importance of their DNA signal in amniotic fluid in this study requires further investigation.

An inherent limitation of molecular investigations is the inability to differentiate between whether the presence of $16 \mathrm{~S}$ rRNA gene signals are due to the presence of viable bacterial communities, dead or metabolically inactive bacterial cells, bacterial cells engulfed or entrapped by host immune cells (154), and/or environmental DNA (103). While many studies have used molecular techniques to confirm the existence of bacterial DNA in the placenta, fetal tissue, and amniotic fluid $(48,75,83-85,96-98,104,105,121)$, only some have attempted to culture bacteria from these same samples $(75,96,105,121)$. Notably, Corynebacterium, Pseudomonas, Sphingobium, Streptococcus, and other prominent bacteria identified in molecular surveys were not recovered in culture in this study. Indeed, the only microorganism that was cultured, Lactobacillus murinus, was cultured from only one mouse and it was not detected in the 16S rRNA gene profile of any amniotic fluid sample in the study. L. murinus is known to reside in the GI system of mice, where it has been documented to play a role in attenuating inflammation (155). Indeed, in a prior study (107), L. murinus was found in multiple body sites of pregnant mice. Given its wide distribution among and within mice, this Lactobacillus isolate may represent a culture cross-contaminant from other murine body sites.

\section{Strengths of This Study}

The current study has three principal strengths. First, we used multiple, complementary modes of inquiry, including $16 \mathrm{~S}$ rRNA gene qPCR, 16S rRNA gene sequencing, and bacterial culture to 
assess whether there is an amniotic fluid microbiota in mice. Furthermore, the culture component of the study included molecular validation. Second, we utilized robust sterile techniques as well as negative, experimental, and positive controls when performing extractions and molecular work to assure that any bacterial DNA signal detected in the experimental samples could be correctly attributed to a true $16 \mathrm{~S}$ rRNA gene signal in the amniotic fluid versus environmental or reagent contamination. Third, we sampled amniotic fluid from amniotic sacs proximal and distal to the cervix to assess differential presence of microorganisms throughout the uterine horns of mice.

\section{Limitations of This Study}

The current study has two principal limitations. First, this study focused exclusively on assessing the presence of bacteria in murine amniotic fluid; viruses and eukaryotic microorganisms were not considered in this study. Second, we used the mouse as a model to evaluate the existence of an amniotic fluid microbiota. Given that there are differences in the physiology and morphology of murine and human reproductive tracts and intra-amniotic environments (156-158), extrapolation of the findings of this study directly to humans may not be appropriate. Also, this study was conducted using a single mouse strain. Future research should consider the potential effect of variation in physiological and morphological characteristics among mouse strains and across animal facilities. Nevertheless, it is important to note that the evaluation of an amniotic fluid microbiota and in utero colonization does not only have translational relevance for human medicine but is also critical for our understanding of mammalian developmental and evolutionary biology in general $(69,159)$.

\section{CONCLUSION}

Using qPCR, 16S rRNA gene sequencing, and bacterial culture, we did not find consistent or reproducible evidence of an amniotic fluid microbiota in mice. This study provides evidence against amniotic fluid as a source of microorganisms for colonization of the fetus and illustrates the importance of implementing multiple methodologies and the appropriate technical controls in investigations assessing microbial profiles of body sites historically presumed to be sterile. However, although this study indicates that the DNA signals detected in murine amniotic fluid samples were not derived from a viable microbiota, this finding does not preclude the importance of in utero exposure to the components and/or products of microorganisms for mammalian fetal development $(100,160)$. This potentiality warrants further investigation.

\section{REFERENCES}

1. Schmidt W. The Amniotic Fluid Compartment: The Fetal Habitat. Adv Anat Embryol Cell Biol (1992) 127:1-100. doi: 10.1007/978-3-642-77300-6

\section{DATA AVAILABILITY STATEMENT}

The datasets presented in this study can be found in online repositories. The names of the repository/repositories and accession number(s) can be found below: https://www.ncbi. nlm.nih.gov/, BioProject ID PRJNA751620.

\section{ETHICS STATEMENT}

The animal study was reviewed and approved by Institutional Animal Care and Use Committee (IACUC) (Protocol No. 1803-0584).

\section{AUTHOR CONTRIBUTIONS}

KT, NG-L, and RR co-conceived the study. AW, JMG, JG, VG-F, and DK performed the laboratory work and data processing. AW, ZS, and KT completed statistical analysis. AW, ZS, JG, NG-L, and KT co-wrote the manuscript. All authors read, edited, and approved the manuscript.

\section{FUNDING}

This research was supported, in part, by the Perinatology Research Branch (PRB), Division of Intramural Research, Eunice Kennedy Shriver National Institute of Child Health and Human Development, National Institutes of Health, U. S. Department of Health and Human Services (NICHD/NIH/DHHS), and, in part, with federal funds from the NICHD/NIH/DHHS under Contract No. HHSN275201300006C. This research was also supported by the Wayne State University Perinatal Initiative in Maternal, Perinatal and Child Health. The funders had no role in the study design, data collection and analysis, decision to publish, or preparation of the manuscript. Dr. Romero has contributed to this work as part of his official duties as an employee of the United States Federal Government.

\section{ACKNOWLEDGMENTS}

The content of this manuscript has previously appeared as a bioRxiv preprint, available at https://www.biorxiv.org/content/ 10.1101/2021.08.10.455893v1.

\section{SUPPLEMENTARY MATERIAL}

The Supplementary Material for this article can be found online at: https://www.frontiersin.org/articles/10.3389/fimmu.2022.820366/ full\#supplementary-material

2. Tarca AL, Romero R, Pique-Regi R, Pacora P, Done B, Kacerovsky M, et al. Amniotic Fluid Cell-Free Transcriptome: A Glimpse Into Fetal Development and Placental Cellular Dynamics During Normal Pregnancy. BMC Med Genomics (2020) 13(1):25. doi: 10.1186/s12920-020-0690-5 
3. Romero R, Wu YK, Oyarzun E, Hobbins JC, Mitchell MD. A Potential Role for Epidermal Growth Factor/Alpha-Transforming Growth Factor in Human Parturition. Eur J Obstet Gynecol Reprod Biol (1989) 33(1):55-60. doi: 10.1016/0028-2243(89)90078-6

4. Lee SE, Han BD, Park IS, Romero R, Yoon BH. Evidence Supporting Proteolytic Cleavage of Insulin-Like Growth Factor Binding Protein-1 (IGFBP-1) Protein in Amniotic Fluid. J Perinat Med (2008) 36(4):316-23. doi: $10.1515 / \mathrm{jpm} .2008 .067$

5. Savasan ZA, Romero R, Chaiworapongsa T, Kusanovic JP, Kim SK, MazakiTovi S, et al. Evidence in Support of a Role for Anti-Angiogenic Factors in Preterm Prelabor Rupture of Membranes. J Matern Fetal Neonatal Med (2010) 23(8):828-41. doi: 10.3109/14767050903440471

6. Romero R, Brody DT, Oyarzun E, Mazor M, King Wu Y, Hobbins JC, et al. Infection and Labor: III. Interleukin-1: A Signal for the Onset of Parturition. Am J Obstet Gynecol (1989) 160(5, Part 1):1117-23. doi: 10.1016/0002-9378 (89)90172-5

7. Romero R, Parvizi ST, Oyarzun E, Mazor M, Wu YK, Avila C, et al. Amniotic Fluid Interleukin-1 in Spontaneous Labor at Term. J Reprod Med (1990) 35(3):235-8.

8. Romero R, Mazor M, Brandt F, Sepulveda W, Avila C, Cotton DB, et al. Interleukin- $1 \alpha$ and Interleukin-1 $\beta$ in Preterm and Term Human Parturition. Am J Reprod Immunol (1992) 27(3-4):117-23. doi: 10.1111/ j.1600-0897.1992.tb00737.x

9. Romero R, Mazor M, Sepulveda W, Avila C, Copeland D, Williams J. Tumor Necrosis Factor in Preterm and Term Labor. Am J Obstet Gynecol (1992) 166 (5):1576-87. doi: 10.1016/0002-9378(92)91636-o

10. Hillier SL, Witkin SS, Krohn MA, Watts DH, Kiviat NB, Eschenbach DA. The Relationship of Amniotic Fluid Cytokines and Preterm Delivery, Amniotic Fluid Infection, Histologic Chorioamnionitis, and Chorioamnion Infection. Obstet Gynecol (1993) 81(6):941-8.

11. Gomez R, Ghezzi F, Romero R, Muñoz H, Tolosa JE, Rojas I. Premature Labor and Intra-Amniotic Infection: Clinical Aspects and Role of the Cytokines in Diagnosis and Pathophysiology. Clin Perinatol (1995) 22 (2):281-342. doi: 10.1016/S0095-5108(18)30286-0

12. Yoon BH, Romero R, Jun JK, Park KH, Park JD, Ghezzi F, et al. Amniotic Fluid Cytokines (Interleukin-6, Tumor Necrosis Factor- $\alpha$, Interleukin-1 $\beta$, and Interleukin-8) and the Risk for the Development of Bronchopulmonary Dysplasia. Am J Obstet Gynecol (1997) 177(4):825-30. doi: 10.1016/S00029378(97)70276-X

13. Hsu C-D, Meaddough E, Aversa K, Copel JA. The Role of Amniotic Fluid LSelectin, GRO- $\alpha$, and Interleukin- 8 in the Pathogenesis of Intraamniotic Infection. Am J Obstet Gynecol (1998) 178(3):428-32. doi: 10.1016/S00029378(98)70414-4

14. Hsu C-D, Meaddough E, Aversa K, Hong S-F, Lu L-C, Jones DC, et al. Elevated Amniotic Fluid Levels of Leukemia Inhibitory Factor, Interleukin 6, and Interleukin 8 in Intra-Amniotic Infection. Am J Obstet Gynecol (1998) 179(5):1267-70. doi: 10.1016/S0002-9378(98)70144-9

15. Hsu C-D, Meaddough E, Hong S-F, Aversa K, Lu L-C, Copel JA. Elevated Amniotic Fluid Nitrix Oxide Metabolites and Interleukin-6 in IntraAmniotic Infection. J Soc Gynecol Investig (1998) 5(1):21-4. doi: 10.1177/ 107155769800500105

16. González-Bosquet E, Cerqueira MJ, Dominguez C, Gasser I, Bermejo B, Cabero L. Amniotic Fluid Glucose and Cytokines Values in the Early Diagnosis of Amniotic Infection in Patients With Preterm Labor and Intact Membranes. J Matern Fetal Med (1999) 8(4):155-8. doi: 10.3109/ 14767059909020480

17. Hsu C-D, Aversa K, Meaddough E. The Role of Amniotic Fluid Interleukin-6, and Cell Adhesion Molecules, Intercellular Adhesion Molecule-1 and Leukocyte Adhesion Molecule-1, in Intra-Amniotic Infection. Am J Reprod Immunol (2000) 43(5):251-4. doi: 10.1111/ j.8755-8920.2000.430501.x

18. Maymon E, Romero R, Pacora P, Gomez R, Athayde N, Edwin S, et al. Human Neutrophil Collagenase (Matrix Metalloproteinase 8) in Parturition, Premature Rupture of the Membranes, and Intrauterine Infection. Am J Obstet Gynecol (2000) 183(1):94-9. doi: 10.1067/mob.2000.105344

19. Harirah H, Donia SE, Hsu C-D. Amniotic Fluid Matrix Metalloproteinase-9 and Interleukin-6 in Predicting Intra-Amniotic Infection. Obstet Gynecol (2002) 99(1):80-4. doi: 10.1016/S0029-7844(01)01632-5
20. Romero R, Grivel J-C, Tarca AL, Chaemsaithong P, Xu Z, Fitzgerald W, et al. Evidence of Perturbations of the Cytokine Network in Preterm Labor. Am J Obstet Gynecol (2015) 213(6):836.e1-18. doi: 10.1016/j.ajog.2015.07.037

21. Romero R, Chaemsaithong P, Korzeniewski SJ, Tarca AL, Bhatti G, Xu Z, et al. Clinical Chorioamnionitis at Term II: The Intra-Amniotic Inflammatory Response. J Perinat Med (2016) 44(1):5-22. doi: 10.1515/ jpm-2015-0045

22. Son G-H, You Y-A, Kwon E-J, Lee K-Y, Kim YJ. Comparative Analysis of Midtrimester Amniotic Fluid Cytokine Levels to Predict Spontaneous Very Pre-Term Birth in Patients With Cervical Insufficiency. Am J Reprod Immunol (2016) 75(2):155-61. doi: 10.1111/aji.12451

23. Tarca AL, Fitzgerald W, Chaemsaithong P, Xu Z, Hassan SS, Grivel JC, et al. The Cytokine Network in Women With an Asymptomatic Short Cervix and the Risk of Preterm Delivery. Am J Reprod Immunol (2017) 78(3):e12686. doi: 10.1111/aji.12686

24. Chaemsaithong P, Romero R, Docheva N, Chaiyasit N, Bhatti G, Pacora P, et al. Comparison of Rapid MMP-8 and Interleukin-6 Point-of-Care Tests to Identify Intra-Amniotic Inflammation/Infection and Impending Preterm Delivery in Patients With Preterm Labor and Intact Membranes. J Matern Fetal Neonatal Med (2018) 31(2):228-44. doi: 10.1080/14767058. 2017.1281904

25. Gomez-Lopez N, Romero R, Panaitescu B, Leng Y, Xu Y, Tarca AL, et al. Inflammasome Activation During Spontaneous Preterm Labor With IntraAmniotic Infection or Sterile Intra-Amniotic Inflammation. Am J Reprod Immunol (2018) 80(5):e13049. doi: 10.1111/aji.13049

26. Bhatti G, Romero R, Rice GE, Fitzgerald W, Pacora P, Gomez-Lopez N, et al. Compartmentalized Profiling of Amniotic Fluid Cytokines in Women With Preterm Labor. PloS One (2020) 15(1):e0227881. doi: 10.1371/ journal.pone. 0227881

27. Musilova I, Andrys C, Holeckova M, Kolarova V, Pliskova L, Drahosova M, et al. Interleukin-6 Measured Using the Automated Electrochemiluminescence Immunoassay Method for the Identification of Intra-Amniotic Inflammation in Preterm Prelabor Rupture of Membranes. J Matern Fetal Neonatal Med (2020) 33(11):1919-26. doi: 10.1080/14767058.2018.1533947

28. Espinoza J, Chaiworapongsa T, Romero R, Edwin S, Rathnasabapathy C, Gomez R, et al. Antimicrobial Peptides in Amniotic Fluid: Defensins, Calprotectin and Bacterial/Permeability-Increasing Protein in Patients With Microbial Invasion of the Amniotic Cavity, Intra-Amniotic Inflammation, Preterm Labor and Premature Rupture of Membranes. J Matern Fetal Neonatal Med (2003) 13(1):2-21. doi: 10.1080/jmf.13.1.2.21

29. Yoshio H, Tollin M, Gudmundsson GH, Lagercrantz H, Jörnvall $H$, Marchini G, et al. Antimicrobial Polypeptides of Human Vernix Caseosa and Amniotic Fluid: Implications for Newborn Innate Defense. Pediatr Res (2003) 53(2):211-6. doi: 10.1203/01.PDR.0000047471.47777.B0

30. Soto E, Espinoza J, Nien JK, Kusanovic JP, Erez O, Richani K, et al. Human $\beta$-Defensin-2: A Natural Antimicrobial Peptide Present in Amniotic Fluid Participates in the Host Response to Microbial Invasion of the Amniotic Cavity. J Matern Fetal Neonatal Med (2007) 20(1):15-22. doi: 10.1080/ 14767050601036212

31. Iavazzo C, Tassis K, Gourgiotis D, Boutsikou M, Baka S, Hassiakos D, et al. The Role of Human Beta Defensins 2 and 3 in the Second Trimester Amniotic Fluid in Predicting Preterm Labor and Premature Rupture of Membranes. Arch Gynecol Obstet (2010) 281(5):793-9. doi: 10.1007/s00404009-1155-4

32. Varrey A, Romero R, Panaitescu B, Miller D, Chaiworapongsa T, Patwardhan M, et al. Human B-Defensin-1: A Natural Antimicrobial Peptide Present in Amniotic Fluid That Is Increased in Spontaneous Preterm Labor With Intra-Amniotic Infection. Am J Reprod Immunol (2018) 80(4):e13031. doi: 10.1111/aji.13031

33. Para R, Romero R, Miller D, Panaitescu B, Varrey A, Chaiworapongsa T, et al. Human $\beta$-Defensin-3 Participates in Intra-Amniotic Host Defense in Women With Labor at Term, Spontaneous Preterm Labor and Intact Membranes, and Preterm Prelabor Rupture of Membranes. J Matern Fetal Neonatal Med (2020) 33(24):4117-32. doi: 10.1080/14767058.2019.1597047

34. Martinez-Varea A, Romero R, Xu Y, Miller D, Ahmed AI, Chaemsaithong P, et al. Clinical Chorioamnionitis at Term VII: The Amniotic Fluid Cellular Immune Response. J Perinat Med (2017) 45(5):523-38. doi: 10.1515/jpm2016-0225 
35. Gomez-Lopez N, Romero R, Xu Y, Miller D, Leng Y, Panaitescu B, et al. The Immunophenotype of Amniotic Fluid Leukocytes in Normal and Complicated Pregnancies. Am J Reprod Immunol (2018) 79(4):e12827. doi: $10.1111 /$ aji.12827

36. Gomez-Lopez N, Romero R, Galaz J, Xu Y, Panaitescu B, Slutsky R, et al. Cellular Immune Responses in Amniotic Fluid of Women With Preterm Labor and Intra-Amniotic Infection or Intra-Amniotic Inflammation. Am J Reprod Immunol (2019) 82(5):e13171. doi: 10.1111/aji.13171

37. Gomez-Lopez N, Romero R, Xu Y, Miller D, Arenas-Hernandez M, GarciaFlores V, et al. Fetal T Cell Activation in the Amniotic Cavity During Preterm Labor: A Potential Mechanism for a Subset of Idiopathic Preterm Birth. J Immunol (2019) 203(7):1793-807. doi: 10.4049/jimmunol.1900621

38. Galaz J, Romero R, Slutsky R, Xu Y, Motomura K, Para R, et al. Cellular Immune Responses in Amniotic Fluid of Women With Preterm Prelabor Rupture of Membranes. J Perinat Med (2020) 48(3):222-33. doi: 10.1515/ jpm-2019-0395

39. Galaz J, Romero R, Xu Y, Miller D, Levenson D, Para R, et al. Cellular Immune Responses in Amniotic Fluid of Women With a Sonographic Short Cervix. J Perinat Med (2020) 48(7):665-76. doi: 10.1515/jpm-2020-0037

40. Galaz J, Romero R, Xu Y, Miller D, Slutsky R, Levenson D, et al. Cellular Immune Responses in Amniotic Fluid of Women With Preterm Clinical Chorioamnionitis. Inflamm Res (2020) 69(2):203-16. doi: 10.1007/s00011019-01308-x

41. Romero R, Emamian M, Quintero R, Wan M, Hobbins JC, Mitchell MD. Amniotic Fluid Prostaglandin Levels and Intra-Amniotic Infections. Lancet (London England) (1986) 1(8494):1380. doi: 10.1016/s0140-6736(86)91685-5

42. Romero R, Emamian M, Quintero R, Wan M, Hobbins JC, Mazor M, et al. The Value and Limitations of the Gram Stain Examination in the Diagnosis of Intraamniotic Infection. Am J Obstet Gynecol (1988) 159(1):114-9. doi: 10.1016/0002-9378(88)90503-0

43. Romero R, Emamian M, Quintero R, Wan M, Scioscia AL, Hobbins JC, et al. Diagnosis of Intra-Amniotic Infection: The Acridine Orange Stain. Am J Perinatol (1989) 6(1):41-5. doi: 10.1055/s-2007-999542

44. Romero R, Sirtori M, Oyarzun E, Avila C, Mazor M, Callahan R, et al. Infection and Labor. V. Prevalence, Microbiology, and Clinical Significance of Intraamniotic Infection in Women With Preterm Labor and Intact Membranes. Am J Obstet Gynecol (1989) 161(3):817-24. doi: 10.1016/ 0002-9378(89)90409-2

45. Romero R, Jimenez C, Lohda AK, Nores J, Hanaoka S, Avila C, et al. Amniotic Fluid Glucose Concentration: A Rapid and Simple Method for the Detection of Intraamniotic Infection in Preterm Labor. Am J Obstet Gynecol (1990) 163(3):968-74. doi: 10.1016/0002-9378(90)91106-m

46. Romero R, Quintero R, Nores J, Avila C, Mazor M, Hanaoka S, et al. Amniotic Fluid White Blood Cell Count: A Rapid and Simple Test to Diagnose Microbial Invasion of the Amniotic Cavity and Predict Preterm Delivery. Am J Obstet Gynecol (1991) 165(4 Pt 1):821-30. doi: 10.1016/00029378(91)90423-o

47. Romero R, Yoon BH, Kenney JS, Gomez R, Allison AC, Sehgal PB. Amniotic Fluid Interleukin-6 Determinations Are of Diagnostic and Prognostic Value in Preterm Labor. Am J Reprod Immunol (New York NY 1989) (1993) 30(23):167-83. doi: 10.1111/j.1600-0897.1993.tb00618.x

48. Gomez R, Romero R, Galasso M, Behnke E, Insunza A, Cotton DB. The Value of Amniotic Fluid Interleukin-6, White Blood Cell Count, and Gram Stain in the Diagnosis of Microbial Invasion of the Amniotic Cavity in Patients at Term. Am J Reprod Immunol (New York NY 1989) (1994) 32 (3):200-10. doi: 10.1111/j.1600-0897.1994.tb01115.x

49. Yoon BH, Romero R, Kim M, Kim EC, Kim T, Park JS, et al. Clinical Implications of Detection of Ureaplasma Urealyticum in the Amniotic Cavity With the Polymerase Chain Reaction. Am J Obstet Gynecol (2000) 183(5):1130-7. doi: 10.1067/mob.2000.109036

50. Yoon BH, Romero R, Moon JB, Shim SS, Kim M, Kim G, et al. Clinical Significance of Intra-Amniotic Inflammation in Patients With Preterm Labor and Intact Membranes. Am J Obstet Gynecol (2001) 185(5):1130-6. doi: $10.1067 / \mathrm{mob} .2001 .117680$

51. Romero R, Miranda J, Chaiworapongsa T, Chaemsaithong P, Gotsch F, Dong Z, et al. A Novel Molecular Microbiologic Technique for the Rapid Diagnosis of Microbial Invasion of the Amniotic Cavity and Intra-Amniotic
Infection in Preterm Labor With Intact Membranes. Am J Reprod Immunol (New York NY 1989) (2014) 71(4):330-58. doi: 10.1111/aji.12189

52. Romero R, Miranda J, Chaiworapongsa T, Korzeniewski SJ, Chaemsaithong P, Gotsch F, et al. Prevalence and Clinical Significance of Sterile IntraAmniotic Inflammation in Patients With Preterm Labor and Intact Membranes. Am J Reprod Immunol (New York NY 1989) (2014) 72 (5):458-74. doi: 10.1111/aji.12296

53. Romero R, Miranda J, Chaemsaithong P, Chaiworapongsa T, Kusanovic JP, Dong $Z$, et al. Sterile and Microbial-Associated Intra-Amniotic Inflammation in Preterm Prelabor Rupture of Membranes. J Matern Fetal Neonatal Med (2015) 28(12):1394-409. doi: 10.3109/14767058.2014.958463

54. Romero R, Miranda J, Chaiworapongsa T, Chaemsaithong P, Gotsch F, Dong $\mathrm{Z}$, et al. Sterile Intra-Amniotic Inflammation in Asymptomatic Patients With a Sonographic Short Cervix: Prevalence and Clinical Significance. J Matern Fetal Neonatal Med (2015) 28(11):1343-59. doi: 10.3109/14767058.2014.954243

55. Romero R, Miranda J, Kusanovic JP, Chaiworapongsa T, Chaemsaithong P, Martinez A, et al. Clinical Chorioamnionitis at Term I: Microbiology of the Amniotic Cavity Using Cultivation and Molecular Techniques. J Perinat Med (2015) 43(1):19-36. doi: 10.1515/jpm-2014-0249

56. Chaemsaithong P, Romero R, Korzeniewski SJ, Martinez-Varea A, Dong Z, Yoon BH, et al. A Point of Care Test for Interleukin-6 in Amniotic Fluid in Preterm Prelabor Rupture of Membranes: A Step Toward the Early Treatment of Acute Intra-Amniotic Inflammation/Infection. J Matern Fetal Neonatal Med (2016) 29 (3):360-7. doi: 10.3109/14767058.2015.1006621

57. Chaemsaithong P, Romero R, Korzeniewski SJ, Martinez-Varea A, Dong Z, Yoon BH, et al. A Rapid Interleukin-6 Bedside Test for the Identification of Intra-Amniotic Inflammation in Preterm Labor With Intact Membranes. J Matern Fetal Neonatal Med (2016) 29(3):349-59. doi: 10.3109/14767058. 2015.1006620

58. Chaiyasit N, Romero R, Chaemsaithong P, Docheva N, Bhatti G, Kusanovic JP, et al. Clinical Chorioamnionitis at Term VIII: A Rapid MMP-8 Test for the Identification of Intra-Amniotic Inflammation. J Perinat Med (2017) 45 (5):539-50. doi: 10.1515/jpm-2016-0344

59. Romero R, Gomez-Lopez N, Winters AD, Jung E, Shaman M, Bieda J, et al. Evidence That Intra-Amniotic Infections Are Often the Result of an Ascending Invasion - A Molecular Microbiological Study. J Perinat Med (2019) 47(9):915-31. doi: 10.1515/jpm-2019-0297

60. Romero R, Dey SK, Fisher SJ. Preterm Labor: One Syndrome, Many Causes. Science (2014) 345(6198):760-5. doi: 10.1126/science.1251816

61. Yoder PR, Gibbs RS, Blanco JD, Castaneda YS, St Clair PJ. A Prospective, Controlled Study of Maternal and Perinatal Outcome After Intra-Amniotic Infection at Term. Am J Obstet Gynecol (1983) 145(6):695-701. doi: 10.1016/ 0002-9378(83)90575-6

62. Espinoza J, Goncalves LF, Romero R, Nien JK, Stites S, Kim YM, et al. The Prevalence and Clinical Significance of Amniotic Fluid 'Sludge' in Patients With Preterm Labor and Intact Membranes. Ultrasound Obstet Gynecol (2005) 25(4):346-52. doi: 10.1002/uog. 1871

63. DiGiulio DB, Romero R, Amogan HP, Kusanovic JP, Bik EM, Gotsch F, et al. Microbial Prevalence, Diversity and Abundance in Amniotic Fluid During Preterm Labor: A Molecular and Culture-Based Investigation. PloS One (2008) 3(8):e3056. doi: 10.1371/journal.pone.0003056

64. DiGiulio DB, Romero R, Kusanovic JP, Gomez R, Kim CJ, Seok KS, et al. Prevalence and Diversity of Microbes in the Amniotic Fluid, the Fetal Inflammatory Response, and Pregnancy Outcome in Women With Preterm Pre-Labor Rupture of Membranes. Am J Reprod Immunol (2010) 64(1):38-57. doi: 10.1111/j.1600-0897.2010.00830.x

65. Combs CA, Gravett M, Garite TJ, Hickok DE, Lapidus J, Porreco R, et al. Amniotic Fluid Infection, Inflammation, and Colonization in Preterm Labor With Intact Membranes. Am J Obstet Gynecol (2014) 210(2):125.e1-15. doi: 10.1016/j.ajog.2013.11.032

66. Kacerovsky M, Musilova I, Andrys C, Hornychova H, Pliskova L, Kostal M, et al. Prelabor Rupture of Membranes Between 34 and 37 Weeks: The Intraamniotic Inflammatory Response and Neonatal Outcomes. Am J Obstet Gynecol (2014) 210(4):325.e1-10. doi: 10.1016/j.ajog.2013.10.882

67. Musilova I, Andrys C, Drahosova M, Zednikova B, Hornychova H, Pliskova L, et al. Late Preterm Prelabor Rupture of Fetal Membranes: Fetal 
Inflammatory Response and Neonatal Outcome. Pediatr Res (2018) 83 (3):630-7. doi: 10.1038/pr.2017.300

68. Thorell A, Hallingstrom M, Hagberg H, Fyhr IM, Tsiartas P, Olsson I, et al. Microbial Invasion of the Amniotic Cavity Is Associated With Impaired Cognitive and Motor Function at School Age in Preterm Children. Pediatr Res (2020) 87(5):924-31. doi: 10.1038/s41390-019-0666-3

69. Perez-Muñoz ME, Arrieta MC, Ramer-Tait AE, Walter J. A Critical Assessment of the "Sterile Womb" and "In Utero Colonization" Hypotheses: Implications for Research on the Pioneer Infant Microbiome. Microbiome (2017) 5(1):48. doi: 10.1186/s40168-017-0268-4

70. Aagaard K, Ma J, Antony KM, Ganu R, Petrosino J, Versalovic J. The Placenta Harbors a Unique Microbiome. Sci Transl Med (2014) 6 (237):237ra265. doi: 10.1126/scitranslmed.3008599

71. Doyle RM, Alber DG, Jones HE, Harris K, Fitzgerald F, Peebles D, et al. Term and Preterm Labour Are Associated With Distinct Microbial Community Structures in Placental Membranes Which Are Independent of Mode of Delivery. Placenta (2014) 35(12):1099-101. doi: 10.1016/ j.placenta.2014.10.007

72. Antony KM, Ma J, Mitchell KB, Racusin DA, Versalovic J, Aagaard K. The Preterm Placental Microbiome Varies in Association With Excess Maternal Gestational Weight Gain. Am J Obstet Gynecol (2015) 212(5):653.e1-16. doi: 10.1016/j.ajog.2014.12.041

73. Zheng J, Xiao X, Zhang Q, Mao L, Yu M, Xu J. The Placental Microbiome Varies in Association With Low Birth Weight in Full-Term Neonates. Nutrients (2015) 7(8):6924-37. doi: 10.3390/nu7085315

74. Bassols J, Serino M, Carreras-Badosa G, Burcelin R, Blasco-Baque V, LopezBermejo A, et al. Gestational Diabetes is Associated With Changes in Placental Microbiota and Microbiome. Pediatr Res (2016) 80(6):777-84. doi: 10.1038/pr.2016.155

75. Collado MC, Rautava S, Aakko J, Isolauri E, Salminen S. Human Gut Colonisation may be Initiated In Utero by Distinct Microbial Communities in the Placenta and Amniotic Fluid. Sci Rep (2016) 6:23129. doi: 10.1038/srep23129

76. Prince AL, Ma J, Kannan PS, Alvarez M, Gisslen T, Harris RA, et al. The Placental Membrane Microbiome is Altered Among Subjects With Spontaneous Preterm Birth With and Without Chorioamnionitis. Am J Obstet Gynecol (2016) 214(5):627.e621-627.e616. doi: 10.1016/ j.ajog.2016.01.193

77. Doyle RM, Harris K, Kamiza S, Harjunmaa U, Ashorn U, Nkhoma M, et al. Bacterial Communities Found in Placental Tissues Are Associated With Severe Chorioamnionitis and Adverse Birth Outcomes. PloS One (2017) 12 (7):e0180167. doi: 10.1371/journal.pone.0180167

78. Gomez-Arango LF, Barrett HL, McIntyre HD, Callaway LK, Morrison M, Nitert MD. Contributions of the Maternal Oral and Gut Microbiome to Placental Microbial Colonization in Overweight and Obese Pregnant Women. Sci Rep (2017) 7(1):2860. doi: 10.1038/s41598-017-03066-4

79. Parnell LA, Briggs CM, Cao B, Delannoy-Bruno O, Schrieffer AE, Mysorekar IU. Microbial Communities in Placentas From Term Normal Pregnancy Exhibit Spatially Variable Profiles. Sci Rep (2017) 7(1):11200. doi: 10.1038/ s41598-017-11514-4

80. Zheng J, Xiao XH, Zhang Q, Mao LL, Yu M, Xu JP, et al. Correlation of Placental Microbiota With Fetal Macrosomia and Clinical Characteristics in Mothers and Newborns. Oncotarget (2017) 8(47):82314-25. doi: 10.18632/ oncotarget.19319

81. Seferovic MD, Pace RM, Carroll M, Belfort B, Major AM, Chu DM, et al. Visualization of Microbes by $16 \mathrm{~S}$ in Situ Hybridization in Term and Preterm Placentas Without Intraamniotic Infection. Am J Obstet Gynecol (2019) 221 (2):146.e1-23. doi: 10.1016/j.ajog.2019.04.036

82. Dinsdale NK, Castaño-Rodríguez N, Quinlivan JA, Mendz GL. Comparison of the Genital Microbiomes of Pregnant Aboriginal and Non-Aboriginal Women. Front Cell Infect Microbiol (2020) 10:523764. doi: 10.3389/ fcimb.2020.523764

83. Rautava S, Collado MC, Salminen S, Isolauri E. Probiotics Modulate HostMicrobe Interaction in the Placenta and Fetal Gut: A Randomized, DoubleBlind, Placebo-Controlled Trial. Neonatology (2012) 102(3):178-84. doi: $10.1159 / 000339182$

84. Stinson LF, Boyce MC, Payne MS, Keelan JA. The Not-So-Sterile Womb: Evidence That the Human Fetus Is Exposed to Bacteria Prior to Birth. Front Microbiol (2019) 10:1124. doi: 10.3389/fmicb.2019.01124
85. Wu S, Yu F, Ma L, Zhao Y, Zheng X, Li X, et al. Do Maternal Microbes Shape Newborn Oral Microbes? Indian J Microbiol (2021) 61(1):16-23. doi: 10.1007/s12088-020-00901-7

86. Younge N, McCann JR, Ballard J, Plunkett C, Akhtar S, Araújo-Pérez F, et al. Fetal Exposure to the Maternal Microbiota in Humans and Mice. JCI Insight (2019) 4(19):e127806. doi: 10.1172/jci.insight.127806

87. Rackaityte E, Halkias J, Fukui EM, Mendoza VF, Hayzelden C, Crawford ED, et al. Viable Bacterial Colonization Is Highly Limited in the Human Intestine in Utero. Nat Med (2020) 26(4):599-607. doi: 10.1038/s41591-020-0761-3

88. Mishra A, Lai GC, Yao LJ, Aung TT, Shental N, Rotter-Maskowitz A, et al. Microbial Exposure During Early Human Development Primes Fetal Immune Cells. Cell (2021) 184(13):3394-409.e3320. doi: 10.1016/ j.cell.2021.04.039

89. Borghi E, Massa V, Severgnini M, Fazio G, Avagliano L, Menegola E, et al. Antenatal Microbial Colonization of Mammalian Gut. Reprod Sci (2019) 26 (8):1045-53. doi: 10.1177/1933719118804411

90. Liu CJ, Liang X, Niu ZY, Jin Q, Zeng XQ, Wang WX, et al. Is the Delivery Mode a Critical Factor for the Microbial Communities in the Meconium? EBioMedicine (2019) 49:354-63. doi: 10.1016/j.ebiom.2019.10.045

91. Gil A, Rueda R, Ozanne SE, van der Beek EM, van Loo-Bouwman C, Schoemaker M, et al. Is There Evidence for Bacterial Transfer via the Placenta and Any Role in the Colonization of the Infant Gut? - a Systematic Review. Crit Rev Microbiol (2020) 46(5):493-507. doi: 10.1080/ 1040841x.2020.1800587

92. Blaser MJ, Devkota S, McCoy KD, Relman DA, Yassour M, Young VB. Lessons Learned From the Prenatal Microbiome Controversy. Microbiome (2021) 9(1):8. doi: 10.1186/s40168-020-00946-2

93. de Goffau MC, Charnock-Jones DS, Smith GCS, Parkhill J. Batch Effects Account for the Main Findings of an In Utero Human Intestinal Bacterial Colonization Study. Microbiome (2021) 9(1):6. doi: 10.1186/s40168-02000949-z

94. Silverstein RB, Mysorekar IU. Group Therapy on In Utero Colonization: Seeking Common Truths and a Way Forward. Microbiome (2021) 9(1):7. doi: 10.1186/s40168-020-00968-w

95. Walter J, Hornef MW. A Philosophical Perspective on the Prenatal In Utero Microbiome Debate. Microbiome (2021) 9(1):5. doi: 10.1186/s40168-02000979-7

96. Zhu L, Luo F, Hu W, Han Y, Wang Y, Zheng H, et al. Bacterial Communities in the Womb During Healthy Pregnancy. Front Microbiol (2018) 9:2163. doi: $10.3389 /$ fmicb.2018.02163

97. Stinson L, Hallingström M, Barman M, Viklund F, Keelan J, Kacerovsky M, et al. Comparison of Bacterial DNA Profiles in Mid-Trimester Amniotic Fluid Samples From Preterm and Term Deliveries. Front Microbiol (2020) 11:415. doi: 10.3389/fmicb.2020.00415

98. Campisciano G, Quadrifoglio M, Comar M, De Seta F, Zanotta N, Ottaviani C, et al. Evidence of Bacterial DNA Presence in Chorionic Villi and Amniotic Fluid in the First and Second Trimester of Pregnancy. Future Microbiol (2021) 16:801-10. doi: 10.2217/fmb-2020-0243

99. Satokari R, Grönroos T, Laitinen K, Salminen S, Isolauri E. Bifidobacterium and Lactobacillus DNA in the Human Placenta. Lett Appl Microbiol (2009) 48(1):8-12. doi: 10.1111/j.1472-765X.2008.02475.x

100. Gomez de Agüero M, Ganal-Vonarburg SC, Fuhrer T, Rupp S, Uchimura Y, Li H, et al. The Maternal Microbiota Drives Early Postnatal Innate Immune Development. Science (2016) 351(6279):1296-302. doi: 10.1126/ science.aad2571

101. Martinez KA2nd, Romano-Keeler J, Zackular JP, Moore DJ, Brucker RM, Hooper C, et al. Bacterial DNA Is Present in the Fetal Intestine and Overlaps With That in the Placenta in Mice. PloS One (2018) 13(5):e0197439. doi: 10.1371/journal.pone.0197439

102. Kliman HJ. Comment on "the Placenta Harbors a Unique Microbiome". Sci Transl Med (2014) 6(254):254le4. doi: 10.1126/scitranslmed.3009864

103. Salter SJ, Cox MJ, Turek EM, Calus ST, Cookson WO, Moffatt MF, et al. Reagent and Laboratory Contamination can Critically Impact SequenceBased Microbiome Analyses. BMC Biol (2014) 12:87. doi: 10.1186/s12915014-0087-z

104. Lim ES, Rodriguez C, Holtz LR. Amniotic Fluid From Healthy Term Pregnancies Does Not Harbor a Detectable Microbial Community. Microbiome (2018) 6(1):87. doi: 10.1186/s40168-018-0475-7 
105. Rehbinder EM, Lødrup Carlsen KC, Staff AC, Angell IL, Landrø L, Hilde K, et al. Is Amniotic Fluid of Women With Uncomplicated Term Pregnancies Free of Bacteria? Am J Obstet Gynecol (2018) 219(3):289.e1-12. doi: 10.1016/ j.ajog.2018.05.028

106. Pulendran B, Davis MM. The Science and Medicine of Human Immunology. Science (2020) 369(6511):eaay4014. doi: 10.1126/science.aay4014

107. Theis KR, Romero R, Greenberg JM, Winters AD, Garcia-Flores V, Motomura K, et al. No Consistent Evidence for Microbiota in Murine Placental and Fetal Tissues. mSphere (2020) 5(1):e00933-19. doi: 10.1128/ mSphere.00933-19

108. Theis KR, Romero R, Winters AD, Jobe AH, Gomez-Lopez N. Lack of Evidence for Microbiota in the Placental and Fetal Tissues of Rhesus Macaques. mSphere (2020) 5(3):e00210-20. doi: 10.1128/mSphere. 00210-20

109. Dickson RP, Erb-Downward JR, Freeman CM, Walker N, Scales BS, Beck JM, et al. Changes in the Lung Microbiome Following Lung Transplantation Include the Emergence of Two Distinct Pseudomonas Species With Distinct Clinical Associations. PloS One (2014) 9(5):e97214. doi: 10.1371/ journal.pone.0097214

110. Kozich JJ, Westcott SL, Baxter NT, Highlander SK, Schloss PD. Development of a Dual-Index Sequencing Strategy and Curation Pipeline for Analyzing Amplicon Sequence Data on the MiSeq Illumina Sequencing Platform. Appl Environ Microbiol (2013) 79(17):5112-20. doi: 10.1128/aem.01043-13

111. Callahan BJ, McMurdie PJ, Rosen MJ, Han AW, Johnson AJ, Holmes SP. DADA2: High-Resolution Sample Inference From Illumina Amplicon Data. Nat Methods (2016) 13(7):581-3. doi: 10.1038/nmeth.3869

112. Davis NM, Proctor DM, Holmes SP, Relman DA, Callahan BJ. Simple Statistical Identification and Removal of Contaminant Sequences in MarkerGene and Metagenomics Data. Microbiome (2018) 6(1):226. doi: 10.1186/ s40168-018-0605-2

113. McMurdie PJ, Holmes S. Phyloseq: An R Package for Reproducible Interactive Analysis and Graphics of Microbiome Census Data. PloS One (2013) 8(4):e61217. doi: 10.1371/journal.pone.0061217

114. Oksanen J, Blanchet F, Friendly M, Kindt R, Legendre P, McGlinn D, et al. Vegan: Community Ecology Package. In: R Package Version 2.5-6. Vienna, Austria: R Foundation for Statistical Computing (2019).

115. Anderson MJ. Permutational Multivariate Analysis of Variance Vol. 26. Auckland: Department of Statistics, University of Auckland (2005). p. 32-46.

116. Segata N, Izard J, Waldron L, Gevers D, Miropolsky L, Garrett WS, et al. Metagenomic Biomarker Discovery and Explanation. Genome Biol (2011) 12 (6):R60. doi: 10.1186/gb-2011-12-6-r60

117. Saitou N, Nei M. The Neighbor-Joining Method: A New Method for Reconstructing Phylogenetic Trees. Mol Biol Evol (1987) 4(4):406-25. doi: 10.1093/oxfordjournals.molbev.a040454

118. Tamura K, Stecher G, Peterson D, Filipski A, Kumar S. MEGA6: Molecular Evolutionary Genetics Analysis Version 6.0. Mol Biol Evol (2013) 30 (12):2725-9. doi: 10.1093/molbev/mst197

119. Bernard KA, Funke G. Corynebacterium. In: Whitman WB, editor. Bergey's Manual of Systematics of Archaea and Bacteria. Hoboken, New Jersey: John Wiley \& Sons (2015). p. 1-70.

120. Torres I, Gimenez E, Pascual T, Bueno F, Huntley D, Martínez M, et al. Short-Term Incubation of Positive Blood Cultures in Brain-Heart Infusion Broth Accelerates Identification of Bacteria by Matrix-Assisted Laser Desorption/Ionization Time-of-Flight Mass-Spectrometry. J Med Microbiol (2017) 66(12):1752-8. doi: 10.1099/jmm.0.000643

121. Rodríguez N, Fernandez C, Zamora Y, Berdasquera D, Rivera JA. Detection of Ureaplasma Urealyticum and Ureaplasma Parvum in Amniotic Fluid: Association With Pregnancy Outcomes. J Matern Fetal Neonatal Med (2011) 24(1):47-50. doi: 10.3109/14767058.2010.482609

122. Grice EA, Segre JA. The Skin Microbiome. Nat Rev Microbiol (2011) 9 (4):244-53. doi: 10.1038/nrmicro2537

123. Moore SG, Ericsson AC, Poock SE, Melendez P, Lucy MC. Hot Topic: 16S rRNA Gene Sequencing Reveals the Microbiome of the Virgin and Pregnant Bovine Uterus. J Dairy Sci (2017) 100(6):4953-60. doi: 10.3168/jds.201712592

124. Guzman CE, Wood JL, Egidi E, White-Monsant AC, Semenec L, Grommen SVH, et al. A Pioneer Calf Foetus Microbiome. Sci Rep (2020) 10(1):17712. doi: $10.1038 / \mathrm{s} 41598-020-74677-7$
125. Husso A, Lietaer L, Pessa-Morikawa T, Grönthal T, Govaere J, Van Soom A, et al. The Composition of the Microbiota in the Full-Term Fetal Gut and Amniotic Fluid: A Bovine Cesarean Section Study. Front Microbiol (2021) 12:626421. doi: 10.3389/fmicb.2021.626421

126. Quercia S, Freccero F, Castagnetti C, Soverini M, Turroni S, Biagi E, et al. Early Colonisation and Temporal Dynamics of the Gut Microbial Ecosystem in Standardbred Foals. Equine Vet J (2019) 51(2):231-7. doi: 10.1111/ evj.12983

127. Zou X, Liu G, Meng F, Hong L, Li Y, Lian Z, et al. Exploring the Rumen and Cecum Microbial Community From Fetus to Adulthood in Goat. Animals (Basel) (2020) 10(9):1639. doi: 10.3390/ani10091639

128. Malmuthuge N, Griebel PJ. Fetal Environment and Fetal Intestine Are Sterile During the Third Trimester of Pregnancy. Vet Immunol Immunopathol (2018) 204:59-64. doi: 10.1016/j.vetimm.2018.09.005

129. Rackaityte E, Halkias J, Fukui EM, Mendoza VF, Hayzelden C, Crawford ED, et al. Corroborating Evidence Refutes Batch Effect as Explanation for Fetal Bacteria. Microbiome (2021) 9(1):10. doi: 10.1186/s40168-020-00948-0

130. Kennedy KM, Gerlach MJ, Adam T, Heimesaat MM, Rossi L, Surette MG, et al. Fetal Meconium Does Not Have a Detectable Microbiota Before Birth. Nat Microbiol (2021) 6(7):865-73. doi: 10.1038/s41564-021-00904-0

131. Robbins JR, Bakardjiev AI. Pathogens and the Placental Fortress. Curr Opin Microbiol (2012) 15(1):36-43. doi: 10.1016/j.mib.2011.11.006

132. Glassing A, Dowd SE, Galandiuk S, Davis B, Chiodini RJ. Inherent Bacterial DNA Contamination of Extraction and Sequencing Reagents may Affect Interpretation of Microbiota in Low Bacterial Biomass Samples. Gut Pathog (2016) 8:24. doi: 10.1186/s13099-016-0103-7

133. de Goffau MC, Lager S, Salter SJ, Wagner J, Kronbichler A, Charnock-Jones DS, et al. Recognizing the Reagent Microbiome. Nat Microbiol (2018) 3 (8):851-3. doi: 10.1038/s41564-018-0202-y

134. Eisenhofer R, Minich JJ, Marotz C, Cooper A, Knight R, Weyrich LS. Contamination in Low Microbial Biomass Microbiome Studies: Issues and Recommendations. Trends Microbiol (2019) 27(2):105-17. doi: 10.1016/ j.tim.2018.11.003

135. Lauder AP, Roche AM, Sherrill-Mix S, Bailey A, Laughlin AL, Bittinger K, et al. Comparison of Placenta Samples With Contamination Controls Does Not Provide Evidence for a Distinct Placenta Microbiota. Microbiome (2016) 4(1):29. doi: 10.1186/s40168-016-0172-3

136. Leiby JS, McCormick K, Sherrill-Mix S, Clarke EL, Kessler LR, Taylor LJ, et al. Lack of Detection of a Human Placenta Microbiome in Samples From Preterm and Term Deliveries. Microbiome (2018) 6(1):196. doi: 10.1186/ s40168-018-0575-4

137. de Goffau MC, Lager S, Sovio U, Gaccioli F, Cook E, Peacock SJ, et al. Human Placenta has No Microbiome But can Contain Potential Pathogens. Nature (2019) 572(7769):329-34. doi: 10.1038/s41586-019-1451-5

138. Theis KR, Romero R, Winters AD, Greenberg JM, Gomez-Lopez N, Alhousseini A, et al. Does the Human Placenta Delivered at Term Have a Microbiota? Results of Cultivation, Quantitative Real-Time PCR, 16s rRNA Gene Sequencing, and Metagenomics. Am J Obstet Gynecol (2019) 220 (3):267.e1-39. doi: 10.1016/j.ajog.2018.10.018

139. Gschwind R, Fournier T, Kennedy S, Tsatsaris V, Cordier AG, Barbut F, et al. Evidence for Contamination as the Origin for Bacteria Found in Human Placenta Rather Than a Microbiota. PloS One (2020) 15(8):e0237232. doi: 10.1371/journal.pone.0237232

140. Olomu IN, Pena-Cortes LC, Long RA, Vyas A, Krichevskiy O, Luellwitz R, et al. Elimination of "Kitome" and "Splashome" Contamination Results in Lack of Detection of a Unique Placental Microbiome. BMC Microbiol (2020) 20(1):157. doi: 10.1186/s12866-020-01839-y

141. Sterpu I, Fransson E, Hugerth LW, Du J, Pereira M, Cheng L, et al. No Evidence for a Placental Microbiome in Human Pregnancies at Term. Am J Obstet Gynecol (2021) 224(3):296.e1-23. doi: 10.1016/j.ajog.2020.08.103

142. Kuperman AA, Zimmerman A, Hamadia S, Ziv O, Gurevich V, Fichtman B, et al. Deep Microbial Analysis of Multiple Placentas Shows No Evidence for a Placental Microbiome. Bjog (2020) 127(2):159-69. doi: 10.1111/14710528.15896

143. Belheouane M, Gupta Y, Künzel S, Ibrahim S, Baines JF. Improved Detection of Gene-Microbe Interactions in the Mouse Skin Microbiota Using HighResolution QTL Mapping of 16S rRNA Transcripts. Microbiome (2017) 5 (1):59. doi: 10.1186/s40168-017-0275-5 
144. Kanmani P, Clua P, Vizoso-Pinto MG, Rodriguez C, Alvarez S, Melnikov V, et al. Respiratory Commensal Bacteria Corynebacterium Pseudodiphtheriticum Improves Resistance of Infant Mice to Respiratory Syncytial Virus and Streptococcus Pneumoniae Superinfection. Front Microbiol (2017) 8:1613. doi: 10.3389/fmicb.2017.01613

145. Deo PN, Deshmukh R. Oral Microbiome: Unveiling the Fundamentals. J Oral Maxillofac Pathol (2019) 23(1):122-8. doi: 10.4103/jomfp.JOMFP_304_18

146. Jung E, Romero R, Yoon BH, Theis KR, Gudicha DW, Tarca AL, et al. Bacteria in the Amniotic Fluid Without Inflammation: Early Colonization vs. Contamination. J Perinat Med (2021) 49(9):1103-21. doi: 10.1515/jpm-20210191. (000010151520210191).

147. Zheng W, Tan TK, Paterson IC, Mutha NV, Siow CC, Tan SY, et al. StreptoBase: An Oral Streptococcus Mitis Group Genomic Resource and Analysis Platform. PloS One (2016) 11(5):e0151908. doi: 10.1371/ journal.pone.0151908

148. Palleroni NJ. Pseudomonas. In: Bergey's Manual of Systematics of Archaea and Bacteria. Hoboken, NJ, USA: John Wiley \& Sons (2015). p. 1-1.

149. Singhvi N, Urvashi FNU, Gundawar K, Gupta V, Korpole S, Lal R. Sphingobium. In: Whitman WB, editor. Bergey's Manual of Systematics of Archaea and Bacteria. Hoboken, New Jersey: John Wiley \& Sons (2021).

150. Young CC, Ho MJ, Arun AB, Chen WM, Lai WA, Shen FT, et al. Sphingobium Olei Sp. Nov., Isolated From Oil-Contaminated Soil. Int J Syst Evol Microbiol (2007) 57(Pt 11):2613-7. doi: 10.1099/ijs.0.65187-0

151. Du J, Singh H, Yang JE, Yin CS, Kook M, Yu H, et al. Sphingobium Soli Sp. Nov. Isolated From Rhizosphere Soil of a Rose. Antonie Van Leeuwenhoek (2015) 108(5):1091-7. doi: 10.1007/s10482-015-0562-8

152. Chaudhary DK, Jeong S-W, Kim J. Sphingobium Naphthae Sp. Nov., With the Ability to Degrade Aliphatic Hydrocarbons, Isolated From OilContaminated Soil. Int J Syst Evol Microbiol (2017) 67(8):2986-93. doi: 10.1099/ijsem.0.002064

153. Ruiter NM, Cnossen TT, Bakker RC, van Keulen PJ. Sphingobium Olei Peritonitis: Peritoneal Dialysis in Turmoil? Perit Dial Int (2013) 33(1):102-3. doi: $10.3747 /$ pdi.2012.00080

154. Gomez-Lopez N, Romero R, Xu Y, Miller D, Unkel R, Shaman M, et al. Neutrophil Extracellular Traps in the Amniotic Cavity of Women With IntraAmniotic Infection: A New Mechanism of Host Defense. Reprod Sci (Thousand Oaks Calif) (2017) 24(8):1139-53. doi: 10.1177/1933719116678690
155. Pan F, Zhang L, Li M, Hu Y, Zeng B, Yuan H, et al. Predominant Gut Lactobacillus Murinus Strain Mediates Anti-Inflammaging Effects in Calorie-Restricted Mice. Microbiome (2018) 6(1):54. doi: 10.1186/s40168018-0440-5

156. Mitchell BF, Taggart MJ. Are Animal Models Relevant to Key Aspects of Human Parturition? Am J Physiol Regul Integr Comp Physiol (2009) 297(3): R525-45. doi: 10.1152/ajpregu.00153.2009

157. Schmidt A, Morales-Prieto DM, Pastuschek J, Fröhlich K, Markert UR. Only Humans Have Human Placentas: Molecular Differences Between Mice and Humans. J Reprod Immunol (2015) 108:65-71. doi: 10.1016/j.jri.2015.03.001

158. Lacroix G, Gouyer V, Gottrand F, Desseyn JL. The Cervicovaginal Mucus Barrier. Int J Mol Sci (2020) 21(21):8266. doi: 10.3390/ijms21218266

159. Funkhouser LJ, Bordenstein SR. Mom Knows Best: The Universality of Maternal Microbial Transmission. PloS Biol (2013) 11(8):e1001631. doi: 10.1371/journal.pbio.1001631

160. Li Y, Toothaker JM, Ben-Simon S, Ozeri L, Schweitzer R, McCourt BT, et al. In Utero Human Intestine Harbors Unique Metabolome, Including Bacterial Metabolites. JCI Insight (2020) 5(21):e138751. doi: 10.1172/jci.insight. 138751

Conflict of Interest: The authors declare that the research was conducted in the absence of any commercial or financial relationships that could be construed as a potential conflict of interest.

Publisher's Note: All claims expressed in this article are solely those of the authors and do not necessarily represent those of their affiliated organizations, or those of the publisher, the editors and the reviewers. Any product that may be evaluated in this article, or claim that may be made by its manufacturer, is not guaranteed or endorsed by the publisher.

Copyright (C) 2022 Winters, Romero, Greenberg, Galaz, Shaffer, Garcia-Flores, Kracht, Gomez-Lopez and Theis. This is an open-access article distributed under the terms of the Creative Commons Attribution License (CC BY). The use, distribution or reproduction in other forums is permitted, provided the original author(s) and the copyright owner(s) are credited and that the original publication in this journal is cited, in accordance with accepted academic practice. No use, distribution or reproduction is permitted which does not comply with these terms. 